\title{
The role of precursor emissions on ground level ozone concentration during summer season in Poland
}

\author{
Kinga Walaszek $^{1}$ (D) Maciej Kryza $^{1} \cdot$ Malgorzata Werner $^{1}$
}

Received: 1 February 2017 / Accepted: 28 September 2017 /

Published online: 23 October 2017

(C) The Author(s) 2017. This article is an open access publication

\begin{abstract}
Three online coupled chemical transport model simulations were analyzed for three summer months of 2015 in Poland. One of them was run with default emission inventory, the other two with $\mathrm{NO}_{\mathrm{x}}$ and VOC emissions reduced by $30 \%$, respectively. Obtained ozone concentrations were evaluated with data from air quality measurement stations and ozone sensitivity to precursor emissions was estimated by ozone concentration differences between simulations and with the use of indicator ratios. They were calculated based on modeled mixing ratios of ozone, total reactive nitrogen and its components, nitric acid and hydrogen peroxide. The results show that the model overestimates ozone concentrations with the largest errors in the morning and evening, which is primarily related to the way vertical mixing is resolved by the model. Better model performance for ozone is achieved in rural than urban environment, as PBL and mixing mechanisms play more significant role in urban areas. Modeled ozone shows mixed sensitivity to precursor concentrations, similarly to other European regions, but indicator ratios have different values than are found in literature, particularly $\mathrm{H}_{2} \mathrm{O}_{2} / \mathrm{HNO}_{3}$ is larger than in southern Europe. However, indicator ratios often differ between locations and transition values need to be established individually for a given region.
\end{abstract}

Keywords Ozone - Air quality modeling · Ozone precursor · Poland · Air pollution · Photochemical indicators

\section{Introduction}

Tropospheric ozone is an important summertime air pollutant and a key component of photochemical smog. Its high concentrations are a result of both precursor emissions and meteorological conditions - solar irradiation, high air temperature and low wind velocity are required for efficient ozone formation, but it also depends on the emissions of its two main

Kinga Wałaszek

kinga.walaszek@uwr.edu.pl

1 Department of Climatology and Atmosphere Protection, University of Wrocław, Wrocław, Poland 
precursors (nitrogen oxides and volatile organic compounds) and their ratio. Nonlinearity of these relationships makes modeling of ozone concentrations and summertime air quality assessment difficult (Sillman 1999a).

In regional air quality models, the main sources of uncertainties include meteorological information, usually derived from meteorological models, and pollutant emissions, which is also usually estimated using proxy data rather than measured directly at the source. In particular, emissions from transport, individual fuel-burning heating devices and emissions from plants (biogenic) are subjects to large estimation uncertainties (Borrego et al. 2002; Guenther et al. 1995; Holnicki and Nahorski 2015; Simpson et al. 1995). All of these factors influence air quality modeling results, and uncertainties in modeled pollutant concentrations need to be evaluated before further analysis. Most commonly used method is statistical evaluation, employing point, satellite and aircraft measurements as reference data. After exploratory analysis, which provides general overview of the data, selected statistical error measures are usually calculated in order to determine how well does the model perform. Chang and Hanna (2004) suggest a set of performance measures for use in air quality modeling studies that allow to see how well does the model compare to the measurements, as well as to compare its performance to other models or model configurations. Those measures include Normalized Mean Bias, Fractional Bias, Normalized Mean Square Error, Pearson's Correlation Coefficient, Factor of Two and Index of Agreement. Another attempt to develop a methodology for model benchmarking has been undertaken within the FAIRMODE initiative, which resulted in DELTA Tool, which provides a complex model evaluation and acceptance criteria (Thunis et al. 2012; Thunis et al. 2013). Many functions designed specifically for air quality model evaluation have been prepared as a part of the OpenAir project within the $\mathrm{R}$ packages (Carslaw and Ropkins 2012).

Over the recent decades, many methods of studying relationships between ozone and its precursors have been developed (Kleinman 2005; Konovalov 2002; Spirig et al. 2002). Some of them are based on reproducing ozone formation conditions in laboratory environment (e.g. Lee et al. 2009), other employ chemical transport models or observational data to estimate ozone interactions in the atmosphere for a particular region (e.g. Ciarelli et al. 2016; van Loon et al. 2007). Because measurements of ozone, nitrogen oxides and volatile organic compounds concentration are difficult to obtain, especially all necessary parameters from a single measurement site, it is useful to support the study with a chemical transport model, for example by estimating how the system would react to a change in precursor emissions. It needs to be pointed out, however, that even when a model shows good representation of observed values it does not imply that it will accurately estimate ozone production sensitivities to precursor emissions (Biswas and Rao 2001; Sillman 1995, 1999b; Sillman and He 2002). This is in part because models use precursor species lumped together and reaction rates are estimated for a whole group, and also because accurate results may come from different configurations of photochemistry, vertical mixing, transport, and dry deposition rates (Mallet and Sportisse 2006; Pierce et al. 1998; Russell and Dennis 2000). Therefore it is useful to evaluate model results based on pollutants other than ozone, e.g. nitrogen oxides $\left(\mathrm{NO}\right.$ and $\left.\mathrm{NO}_{2}\right)$ and carbon monoxide (CO), which all take part in reactions that lead to ozone formation (von Kuhlmann et al. 2003).

As mentioned earlier, the relationships between ozone and its precursors are nonlinear and depend on their emissions, reactivity (particularly VOC, which includes tens of chemical species of various chemical reactivities) and concentration ratios between $\mathrm{NO}_{\mathrm{x}}$ and VOC. In general, in situations with high VOC and low $\mathrm{NO}_{\mathrm{x}}$ concentrations, $\mathrm{O}_{3}$ tends to increase with increasing $\mathrm{NO}_{\mathrm{x}}$ and experience little change with increasing VOC. This type of ozone 
formation regime is frequently described as $\mathrm{NO}_{\mathrm{x}}$-sensitive. When $\mathrm{NO}_{\mathrm{x}}$ concentrations are high and VOCs are low, $\mathrm{O}_{3}$ decreases with increasing $\mathrm{NO}_{\mathrm{x}}$ and increases with increasing VOC (VOC-sensitive or $\mathrm{NO}_{\mathrm{x}}$-saturated regime). One method of estimating ozone sensitivity to precursor emissions with the aid of chemical transport models is by examining the ratios of certain species (i.e. indicator ratios) that are different for $\mathrm{NO}_{\mathrm{x}}$-sensitive and VOC-sensitive conditions (Milford et al. 1994; Sillman 1995; Sillman et al. 1998). For example, under $\mathrm{NO}_{\mathrm{x}^{-}}$ sensitive conditions, production rate of peroxides is generally larger than that of $\mathrm{HNO}_{3}$, and the opposite is true for VOC-sensitive conditions. The indicator ratio of $\mathrm{H}_{2} \mathrm{O}_{2} / \mathrm{HNO}_{3}$ should therefore provide information on ozone production conditions. For situations with no rapid removal processes (rainfall or dry deposition) these rates can be approximated by ambient concentrations. On the other hand, there is also a pattern in correlation between $\mathrm{O}_{3}$ and total reactive nitrogen $\left(\mathrm{NO}_{\mathrm{y}}\right)$, which is a sum of $\mathrm{NO}_{\mathrm{x}}\left(\mathrm{NO}\right.$ and $\left.\mathrm{NO}_{2}\right)$ and its oxidation products $\left(\mathrm{NO}_{3}, \mathrm{HNO}_{3}, \mathrm{~N}_{2} \mathrm{O}_{5}\right.$, PAN and other nitrates), which encompasses two processes: firstly, $\mathrm{O}_{3} /$ $\mathrm{NO}_{\mathrm{z}}$ ratio (where $\mathrm{NO}_{\mathrm{z}}=\mathrm{NO}_{\mathrm{y}}-\mathrm{NO}_{\mathrm{x}}$ ) reflects the process of photochemical production of $\mathrm{O}_{3}$, and secondly, $\mathrm{NO}_{\mathrm{x}}$ titration (immediate removal of $\mathrm{O}_{3}$ by reacting with primary $\mathrm{NO}$ ). Analysis of these indicator ratios helps to better understand the chemistry of ozone and other components of photochemical smog and also to design more effective control strategies to reduce $\mathrm{O}_{3}$ concentrations.

In this study, the role of anthropogenic NMVOC and $\mathrm{NO}_{\mathrm{x}}$ emission abatement on ozone concentrations is assessed for summer season, when high ozone concentrations were observed in Poland. The main motivation is to assess the sensitivity of ozone concentrations to anthropogenic emissions of its precursors $\left(\mathrm{NO}_{\mathrm{x}}\right.$ and VOC). It is analyzed how $\mathrm{NO}_{\mathrm{x}}$ and VOC emissions affects the exceedance of critical levels of $\mathrm{O}_{3}$ in Poland. The findings will support ozone precursor emission control strategies during frequent spring and summer time high ozone episodes in this part of Europe.

\section{Data and methods}

\subsection{Study period}

Critical levels of ozone are frequently exceeded in Poland, and majority of these exceedances take place during late spring and summer. In voivodeships located in the western part of the country, the threshold number of days with high ozone levels set by air quality standards ( 25 days with 8-h running mean $\mathrm{O}_{3}$ concentration of $120 \mathrm{\mu g} \mathrm{m}^{-3}$ ) is exceeded almost every year. In this study, the summer months of 2015 (June, July and August) are analyzed. During this time, hourly ozone concentration threshold of $180 \mu \mathrm{g} \mathrm{m}^{-3}$ was exceeded at 36 measurement sites, mostly in urban environments, and multiple high ozone episodes were observed. It is because during these months high pressure systems dominated over the area of Poland, with weak advection from the West. It resulted in many cloud free days with high air temperatures, favorable for ozone formation. The most severe episode took place during the first decade of August. During this time, a vast high pressure system prevailed over the entire Europe, with center in the East of Poland. At the same time, a low pressure system was located over Scandinavia, causing weak advection from the West in Central Europe, both at the surface and upper air. This synoptic situation is common also to other severe ozone episodes in this region, e.g. July 2006 (Wałaszek et al. 2014b) and June 2008 (Wałaszek et al. 2016). However, to the authors' knowledge, the severe August 2015 ozone episode has not been studied in this region yet. 


\subsection{Model description}

In this study, the Weather Research and Forecasting model with Chemistry (WRF-Chem) version 3.6.1 was used with two nested domains. The outer domain covers Europe at a $12 \mathrm{~km} \times 12 \mathrm{~km}$ grid and the inner domain is focused on the area of Poland at $4 \mathrm{~km} \times 4 \mathrm{~km}$ resolution (Fig. 1). The model operates on 35 eta levels, from the surface to $5 \mathrm{hPa}$, with the first model level thickness of ca. $50 \mathrm{~m}$. Land use is derived from CORINE Land Cover database. The model physical parameterizations included Morrison Double Moment microphysics (Morrison et al. 2009), RRTMG long- and shortwave radiation (Iacono et al. 2008), NOAH Land Surface model, Yonsei University PBL scheme (Alapaty et al. 2008), with inclusion of urban canopy model and Grell 3D cumulus for the outer domain. Chemistry scheme was RADM2 for gases and MADE/SORGAM for aerosols. Chemical dynamic

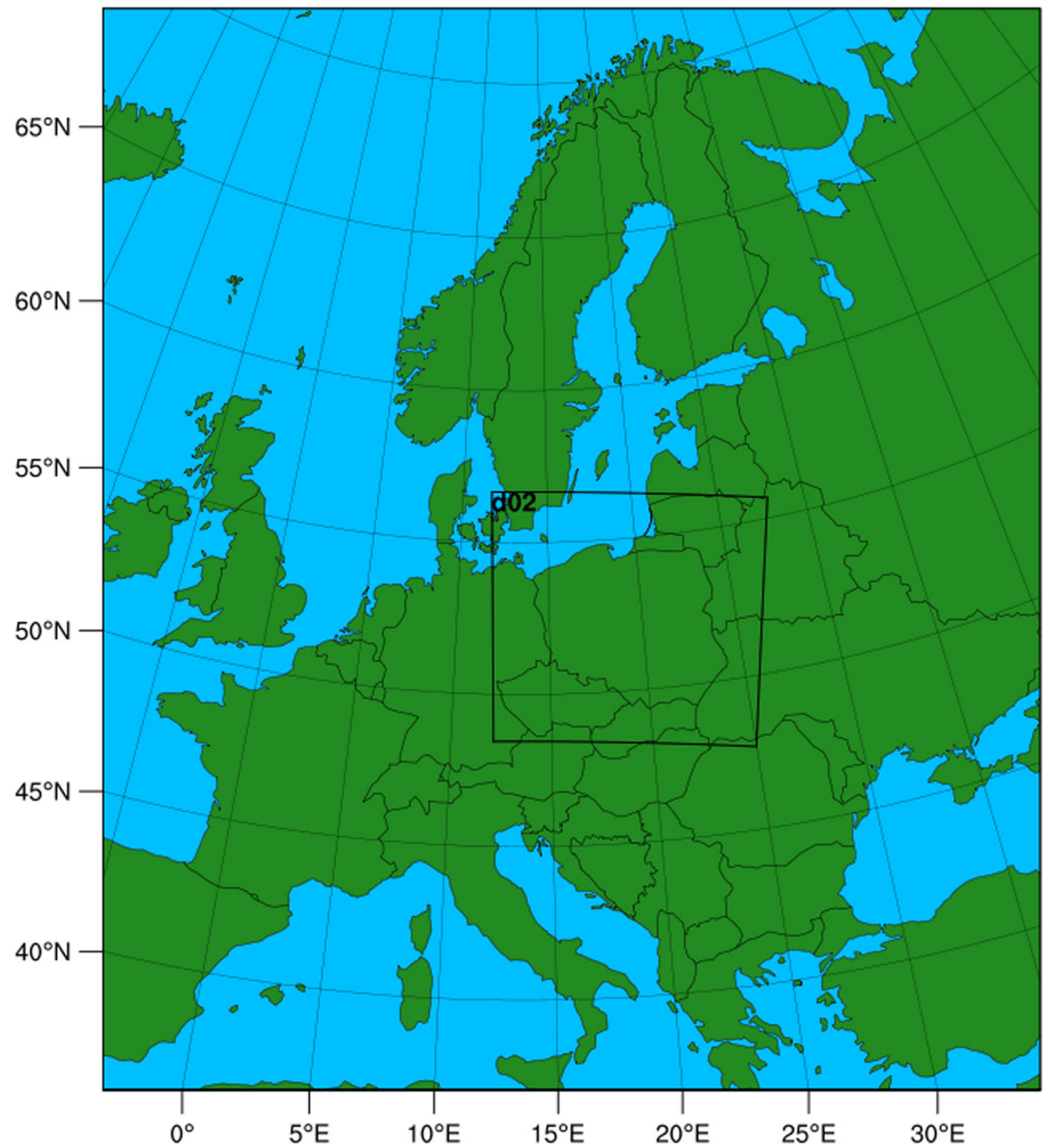

Fig. 1 WRF-Chem model domains 
boundary conditions were prepared with the MOZART global chemical transport model (Emmons et al. 2010) and biogenic emissions were calculated with the MEGAN module for WRF-Chem, based on MEGAN 2003 global biogenic emissions (Guenther et al. 2006). Sea aerosols were also included, using the Gong scheme (Gong 2003). Anthropogenic emissions used were the TNO MACC III European emission inventory for the year 2011 (Kuenen et al. 2014). Hourly temporal anthropogenic emission profile was based on Friedrich and Reis (2004). The emissions were distributed to five vertical layers according to methodology proposed by Bieser et al. (2011), with vertical distributions different for each SNAP sector.

Three model simulations were performed: one with configuration as described above (BASE), and two with modified anthropogenic emission inventories. In one of them, national emission of nitrogen oxides from Poland was reduced by $30 \%$ (NOX30), and in the other one the same percentage reduction of national volatile organic compounds emissions (VOC30) was applied. The purpose of this emission reduction is to determine the sensitivity of ozone concentrations to emissions of VOCs and $\mathrm{NO}_{\mathrm{x}}$. According to Sillman and $\mathrm{He}$ (2002), a regime is considered $\mathrm{NO}_{\mathrm{x}}$-sensitive, when significant reduction of $\mathrm{NO}_{\mathrm{x}}$ emissions (25-50\%) causes a decrease in $\mathrm{O}_{3}$ concentrations of at least 2 ppb and VOC-sensitive, when the same decrease is observed as a response to the same percentage of VOC emissions reduction. In many studies this reduction is set at 30 or 35\% (e.g. Sillman 1995; Andreani-Aksoyoglu and Keller 1997; Castell et al. 2010), also in this study to make it more comparable. Only emissions from Poland were modified to ensure a reduction that can be achieved by legal regulations within the country, and to estimate the role of local precursor sources on ozone concentrations (Sierra et al. 2013). According to Poland's latest Informative Inventory Report (Dębski et al. 2016), a total of $723.1 \mathrm{Gg}$ of $\mathrm{NO}_{\mathrm{x}}$ and $606.3 \mathrm{Gg}$ of non-methane volatile organic compounds (NMVOC) were released to the atmosphere in 2014 by human activities. Although it is a decrease compared to previous year by $6 \%$ and $2 \%$, respectively, over the last decade NMVOC emissions have not been steadily decreasing, like it did in most European countries. Emission totals of both $\mathrm{NO}_{\mathrm{x}}$ and NMVOC are still very high in Poland - only 5 EU member states have higher emissions of these species (according to emission data officially reported to EMEP; www.ceip.at) - and contribute to exceedance of critical ozone levels in Poland.

\subsection{Model evaluation}

First, the BASE simulation was evaluated in terms of ozone concentrations. Data from 78 measurement sites in Poland was used for evaluation, including 56 urban, 18 rural and 4 suburban sites (Fig. 2). Full list of measurement sites is given in Table 1 in the appendix. Two sites were highlighted, Wrocław urban background and Czerniawa rural background station. These sites were selected as representatives of urban and rural environment in Lower Silesia voivodeship, which is one of the regions most affected by high ozone concentrations in Poland, hence it is the area that we focus on. Part of the analysis was performed separately for urban and rural sites. The model performance was summarized using the scatterplot of $\mathrm{O}_{3}$ concentrations averaged over the study period and more detailed analysis with the use of six model performance statistics. Normalized mean bias (NMB) and fractional bias (FB) provide systematic error between measurements and model estimations, whereas normalized mean square error (NMSE) takes into account also random error. Factor of two (FAC2) and index of agreement (d) show general agreement between model values and observations. Formulae and summary of statistics used in the analysis is given in Table 2 in the appendix. These statistics were selected in order to be able to compare the results with studies for other models, regions and seasons. They are widely used in air quality model evaluation and 


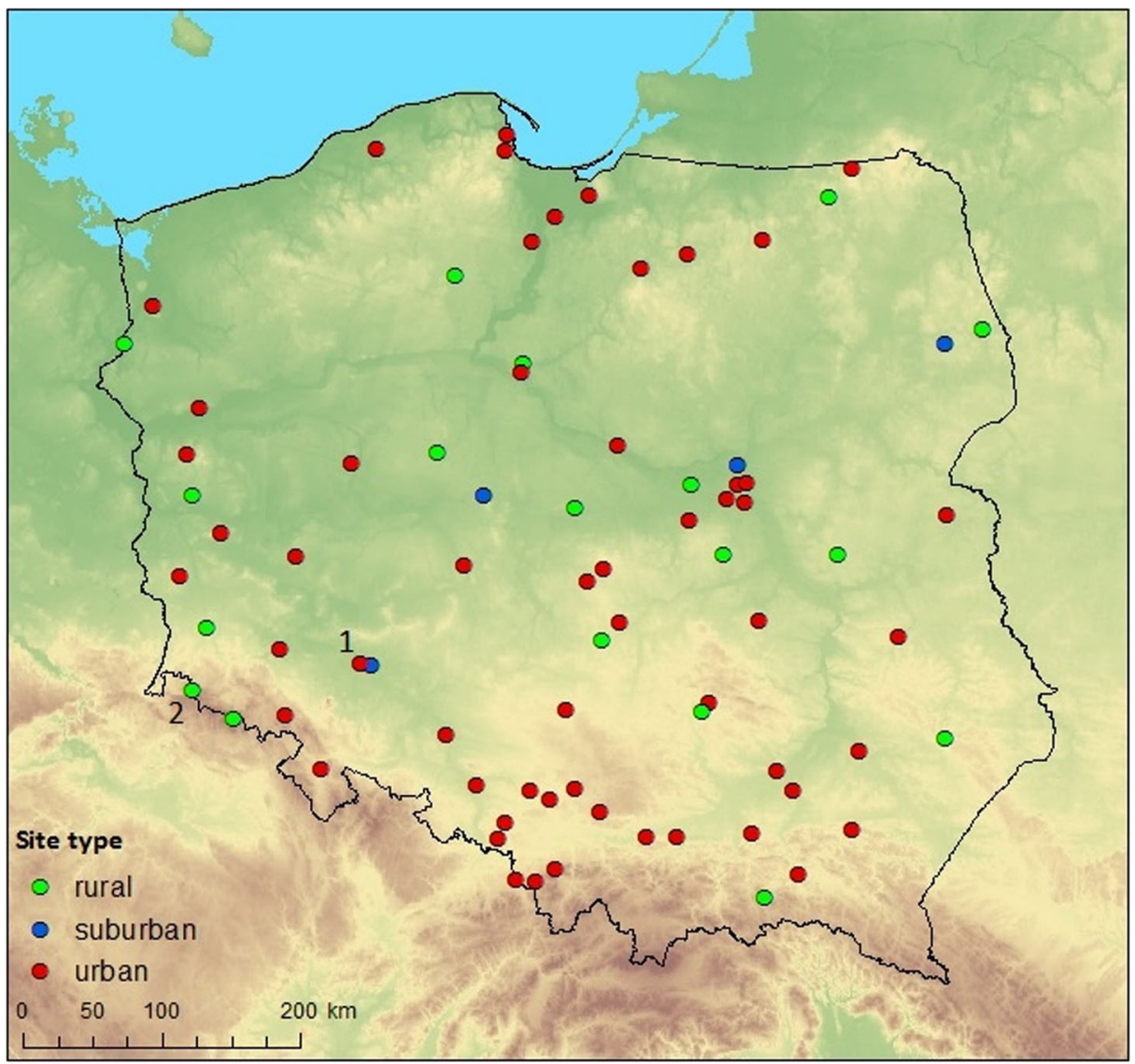

Fig. 2 Air quality measurement sites used in the study, 1 - Wrocław Korzeniowskiego, 2 - Czerniawa

normalized statistics are easy to compare for different setups (Campbell et al. 2015; Zhang et al. 2009). Next, Normalized Mean Error (NME) values for each hour averaged over the study period were analyzed in order to determine any patterns in diurnal variability of model performance.

Delta tool version 5.4 was used to plot target diagram, Model Performance Criteria (MPC) correlation and MPC standard deviation diagrams. MPC are a set of criteria designed to assess the suitability of the model to a given application and are defined by Thunis et al. (2012). All plots were based on 8-h maximum values of $\mathrm{O}_{3}$ concentrations. First, two measures need to be defined: Model Quality Objective (MQO) and Model Quality Indicator (MQI). MQO is defined as the minimum level of quality to be achieved by a model for policy use. MQI is defined as the ratio between the model-measured bias and a quantity proportional to the measurements uncertainty as:

$$
M Q I=\frac{\left|P_{i}-O_{i}\right|}{\beta U_{95}\left(P_{i}\right)}
$$

with $\beta$ equal to 2 in the current formulation. The MQO is fulfilled when MQI is less or equal to 1.

The MQI is used as the main indicator in the target plot diagram. It represents the distance between the origin and a given station point. The normalized bias is used for vertical axis while the centered root mean square error is used to define the $\mathrm{x}$ axis. The MQI associated to the 90th 
Table 1 List of air quality measurement sites used for model evaluation

\begin{tabular}{|c|c|c|c|c|c|c|}
\hline No. & AirBASE code & Location name & lat $\left[{ }^{\circ} \mathrm{N}\right]$ & lon $\left[{ }^{\circ} \mathrm{E}\right]$ & alt $[\mathrm{m}]$ & Type \\
\hline 1 & PL0002R & Jarczew & 51.814367 & 21.972375 & 180 & rural \\
\hline 2 & PL0003R & Śnieżka & 50.736389 & 15.739722 & 1603 & rural \\
\hline 3 & PL0005R & KMŚ Puszcza Borecka & 54.124819 & 22.038056 & 157 & rural \\
\hline 4 & PL0008A & Katowice & 50.264611 & 18.975028 & 273 & urban \\
\hline 5 & PL0014A & Belsk & 51.83512 & 20.791556 & 180 & rural \\
\hline 6 & PL0028A & Czerniawa & 50.912475 & 15.31219 & 645 & rural \\
\hline 7 & PL0029A & Ustroń & 49.724722 & 18.825 & 416 & urban \\
\hline 8 & PL0031A & Konin & 52.225633 & 18.269036 & 103 & suburban \\
\hline 9 & PL0044A & Warszawa & 52.280939 & 20.962156 & 98 & urban \\
\hline 10 & PL0048A & Gdynia & 54.560836 & 18.493331 & 70 & urban \\
\hline 11 & PL0066A & Ciechocinek & 52.888553 & 18.781044 & 44 & urban \\
\hline 12 & PL0068A & Koniczynka & 53.080647 & 18.684258 & 85 & rural \\
\hline 13 & PL0071A & Toruń & 53.028647 & 18.666103 & 65 & urban \\
\hline 14 & PL0077A & Bory Tucholskie & 53.662117 & 17.934017 & 40 & rural \\
\hline 15 & PL0079A & Biała Podlaska & 52.029194 & 23.149389 & 144 & urban \\
\hline 16 & PL0086A & Lublin & 51.259269 & 22.568522 & 270 & urban \\
\hline 17 & PL0094A & Gajew & 52.14325 & 19.233225 & 177 & rural \\
\hline 18 & PL0096A & Łódź & 51.75805 & 19.529786 & 235 & urban \\
\hline 19 & PL0104A & Pabianice & 51.667981 & 19.368683 & 186 & urban \\
\hline 20 & PL0105A & Parzniewice & 51.291175 & 19.517556 & 166 & rural \\
\hline 21 & PL0121A & Szymbark & 49.633714 & 21.116833 & 327 & rural \\
\hline 22 & PL0128A & Granica KPN & 52.285858 & 20.454653 & 81 & rural \\
\hline 23 & PL0129A & Legionowo & 52.407578 & 20.955928 & 95 & suburban \\
\hline 24 & PL0134A & Piastów & 52.191728 & 20.837489 & 103 & urban \\
\hline 25 & PL0138A & Radom & 51.399084 & 21.147474 & 173 & urban \\
\hline 26 & PL0141A & Warszawa - Ursynów & 52.160772 & 21.033819 & 102 & urban \\
\hline 27 & PL0143A & Warszawa - Targówek & 52.290864 & 21.042458 & 85 & urban \\
\hline 28 & PL0144A & Żyrardów & 52.053811 & 20.429892 & 119 & urban \\
\hline 29 & PL0149A & Białystok & 53.138614 & 23.229903 & 146 & suburban \\
\hline 30 & PL0150A & Borsukowizna & 53.218786 & 23.642069 & 180 & rural \\
\hline 31 & PL0171A & Słupsk & 54.463611 & 17.046722 & 25 & urban \\
\hline 32 & PL0175A & Olsztyn & 53.789233 & 20.486075 & 120 & urban \\
\hline 33 & PL0176A & Ostróda & 53.692469 & 19.969778 & 120 & urban \\
\hline 34 & PL0182A & Widuchowa & 53.122319 & 14.382308 & 15 & rural \\
\hline 35 & PL0184A & Częstochowa & 50.836389 & 19.130111 & 265 & urban \\
\hline 36 & PL0190A & Legnica & 51.204503 & 16.180513 & 122 & urban \\
\hline 37 & PL0192A & Wałbrzych & 50.768729 & 16.269677 & 436 & urban \\
\hline 38 & PL0193A & Wrocław - Bartnicza & 51.115933 & 17.141125 & 120 & suburban \\
\hline 39 & PL0194A & Wrocław - Korzeniowskiego & 51.129378 & 17.02925 & 121 & urban \\
\hline 40 & PL0209A & Gorzów Wielkopolski & 52.738214 & 15.228667 & 22 & urban \\
\hline 41 & PL0211A & Smolary Bytnickie & 52.172222 & 15.206667 & 77 & rural \\
\hline 42 & PL0212A & Wschowa & 51.799722 & 16.3175 & 90 & urban \\
\hline 43 & PL0213A & Zielona Góra & 51.939783 & 15.518861 & 150 & urban \\
\hline 44 & PL0218A & Kędzierzyn-Koźle & 50.349608 & 18.236575 & 189 & urban \\
\hline 45 & PL0221A & Opole & 50.666961 & 17.922797 & 134 & urban \\
\hline 46 & PL0223A & Mielec & 50.296667 & 21.435833 & 175 & urban \\
\hline 47 & PL0234A & Bielsko-Biała & 49.813464 & 19.027318 & 365 & urban \\
\hline 48 & PL0236A & Cieszyn & 49.738136 & 18.639069 & 353 & urban \\
\hline 49 & PL0237A & Dąbrowa Górnicza & 50.329111 & 19.231222 & 293 & urban \\
\hline 50 & PL0239A & Rybnik & 50.111181 & 18.516139 & 245 & urban \\
\hline 51 & PL0241A & Wodzisław Śląski & 50.007629 & 18.455548 & 271 & urban \\
\hline 52 & PL0242A & Zabrze & 50.3165 & 18.772375 & 255 & urban \\
\hline 53 & PL0245A & Poznań & 52.420319 & 16.877289 & 84 & urban \\
\hline 54 & PL0247A & WKP Krzyżówka & 52.501389 & 17.773464 & 122 & rural \\
\hline 55 & PL0248A & Szczecin & 53.380975 & 14.663347 & 17 & urban \\
\hline 56 & PL0276A & Nisko & 50.529892 & 22.112467 & 155 & urban \\
\hline
\end{tabular}


Table 1 (continued)

\begin{tabular}{lllllll}
\hline No. & AirBASE code & Location name & lat $\left[{ }^{\circ} \mathrm{N}\right]$ & lon $\left[{ }^{\circ} \mathrm{E}\right]$ & alt $[\mathrm{m}]$ & Type \\
\hline 57 & PL0283A & Kielce & 50.872549 & 20.604998 & 275 & urban \\
58 & PL0295A & Elblag & 54.167847 & 19.410942 & 16 & urban \\
59 & PL0296A & Mragowo & 53.866133 & 21.296122 & 150 & urban \\
60 & PL0312A & Gołdap & 54.305908 & 22.307681 & 167 & urban \\
61 & PL0349A & Biały Słup & 50.590806 & 22.997889 & 240 & rural \\
62 & PL0398A & Płock & 52.556279 & 19.687672 & 104 & urban \\
63 & PL0429A & Malbork & 54.031667 & 19.034167 & 30 & urban \\
64 & PL0464A & Kalisz & 51.775 & 18.080556 & 100 & urban \\
65 & PL0487A & Szarów & 50.007014 & 20.258475 & 230 & urban \\
66 & PL0495A & Rzeszów & 50.024242 & 22.010575 & 200 & urban \\
67 & PL0501A & Kraków & 50.010575 & 19.949189 & 230 & urban \\
68 & PL0502A & Tarnów & 50.020169 & 21.004167 & 230 & urban \\
69 & PL0504A & Kłodzko & 50.433493 & 16.65366 & 300 & urban \\
70 & PL0505A & Osieczów & 51.31763 & 15.431719 & 190 & rural \\
71 & PL0509A & Piotrków Trybunalski & 51.404406 & 19.696956 & 195 & urban \\
72 & PL0514A & Zary & 51.6415 & 15.1275 & 160 & urban \\
73 & PL0518A & Jasło & 49.744886 & 21.454617 & 225 & urban \\
74 & PL0520A & Gdynia & 54.465758 & 18.464911 & 147 & urban \\
75 & PL0552A & Trzebinia & 50.159406 & 19.477464 & 340 & urban \\
76 & PL0563A & Nowiny & 50.823108 & 20.533506 & 244 & rural \\
77 & PL0565A & Połaniec & 50.429014 & 21.277367 & 188 & urban \\
78 & PL0575A & Sulęcin & 52.437722 & 15.122444 & 86 & urban \\
\hline & & & & & &
\end{tabular}

percentile worst station is calculated and indicated in the upper left corner. It is meant to be used as the main indicator in the benchmarking procedure and should be less or equal to one. The uncertainty parameters used to produce the diagram are listed on the top right-hand side. For more details please see Thunis et al. (2016).

MPC correlation diagram plots correlation as a function of the quadratic mean of the uncertainty divided by the station observed standard deviation. For each station (represented by a symbol) it provides an indication of whether the time correlation fulfills a minimum level of quality (green/orange area). MPC standard deviation diagram plots Normalised Mean Standard Deviation (NMSD) as a function of the quadratic mean of the uncertainty divided by the station observed standard deviation. It provides an indication of whether the NMSD fulfills a minimum level of quality for each station.

\subsection{Indicator ratios}

According to definition by Sillman and $\mathrm{He}$ (2002), conditions are described as $\mathrm{NO}_{\mathrm{x}}$-sensitive when a reduction in $\mathrm{NO}_{\mathrm{x}}$ emissions by $25-50 \%$ results in a significant decrease in ambient ozone mixing ratio, larger than in the VOC-reduced scenario. VOC-sensitive $\left(\mathrm{NO}_{\mathrm{x}}\right.$-saturated) conditions are defined analogously for reduction in VOC emissions. If neither of the criteria is fulfilled, conditions are considered as mixed (Liang et al. 2006; Peng et al. 2011). Regarding this definition, differences in $\mathrm{O}_{3}$ concentrations between emission scenarios, averaged over the entire study period, are calculated for each grid point and presented as maps. Ozone sensitivity is also reflected by indicator ratios, and two of these indices are calculated for afternoon ozone peak hours (11-16 UTC): $\Delta \mathrm{O}_{3} /$ $\mathrm{NO}_{\mathrm{y}}$ and $\mathrm{H}_{2} \mathrm{O}_{2} / \mathrm{HNO}_{3}$. $\mathrm{NO}_{y}$ may serve as a good measure of $\mathrm{NO}_{\mathrm{x}}$ emissions during the day, and it shows clearer relationship with ozone than $\mathrm{NO}_{\mathrm{x}}$ because of its atmospheric lifetime, which is similar to $\mathrm{O}_{3}$ - therefore it is considered a good indicator of $\mathrm{O}_{3}$ sensitivity, with high $\mathrm{NO}_{\mathrm{y}}$ values indicating 


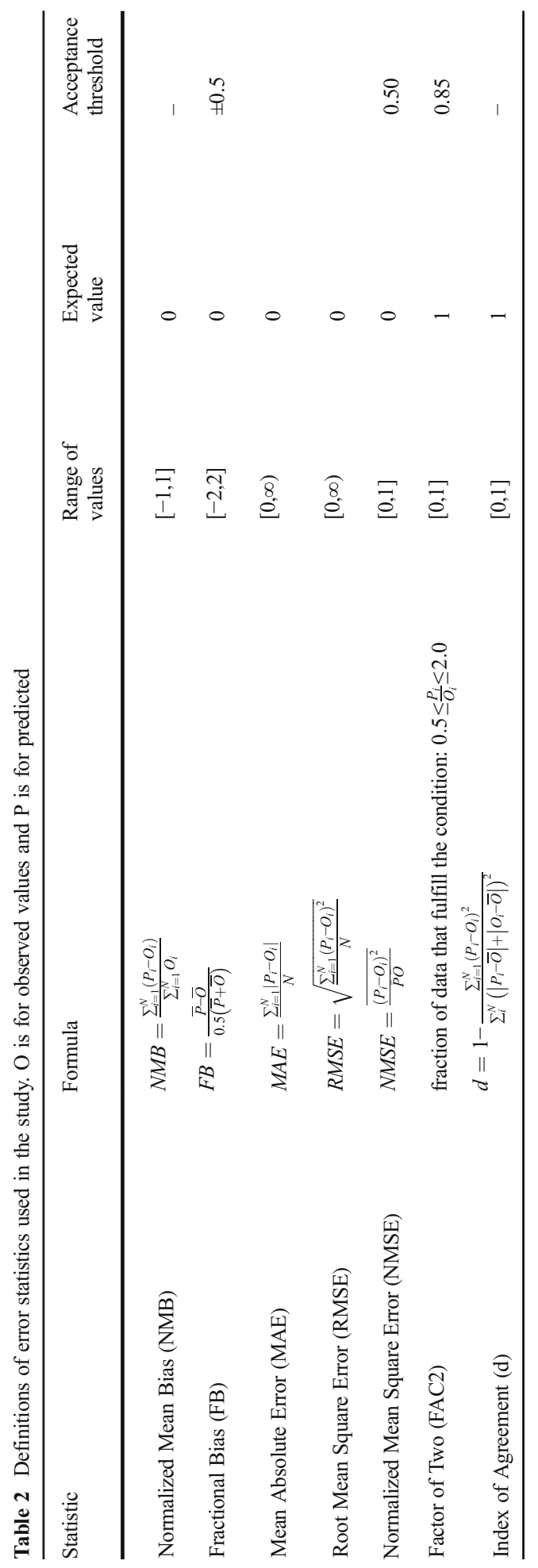


VOC sensitivity (Milford et al. 1994). If we refer that to the change in ambient mixing ratio between BASE and either of the emission control simulations, high $\Delta \mathrm{O}_{3} / \mathrm{NO}_{\mathrm{y}}$ indicates $\mathrm{NO}_{\mathrm{x}}$-sensitive regime, and low $\Delta \mathrm{O}_{3} / \mathrm{NO}_{\mathrm{y}}-\mathrm{VOC}$-sensitive (Chock et al. 1999). The second indicator shows less direct relationship $-\mathrm{H}_{2} \mathrm{O}_{2}$ is formed by reaction of $\mathrm{HO}_{2}$ radicals, and high $\mathrm{N}_{2} \mathrm{O}_{2}$ indicates lack of $\mathrm{NO}$ molecules that $\mathrm{HO}_{2}$ would otherwise react with to form $\mathrm{NO}_{2}$. $\mathrm{HNO}_{3}$ is a major radical sink, which forms by their reaction with $\mathrm{NO}_{2}$ and is associated with high $\mathrm{NO}_{\mathrm{x}}$ emissions. With high $\mathrm{H}_{2} \mathrm{O}_{2}$ / $\mathrm{HNO}_{3}$ ratio the conditions are usually $\mathrm{NO}_{\mathrm{x}}$-sensitive, and with low values - VOC sensitive. Sillman and $\mathrm{He}$ (2002) estimated the transition value between $\mathrm{NO}_{\mathrm{x}}$-sensitive and VOC-sensitive regimes at 0.35 , however because dry deposition rate of $\mathrm{HNO}_{3}$ is higher than $\mathrm{H}_{2} \mathrm{O}_{2}$, which can inflate this ratio in some cases.

The ratio of change in $\mathrm{O}_{3}$ mixing ratio to its ambient concentration is also given for peak hours. All these indicator ratios are presented for measurement station locations with distinction of urban background and rural background conditions. The reason for this approach is to find out to what extent does ozone formation regime depend on environment and what regulatory measures would be the most effective for different parts of Poland. In general, the conditions are expected to be $\mathrm{NO}_{\mathrm{x}}$-sensitive in rural areas and VOC-sensitive in urban environment (Aksoyoglu et al. 2012).

\section{Results and discussion}

\subsection{Model evaluation}

Figure 3 presents measured and modeled hourly ozone concentrations averaged for each site over the study period, with distinction of site type. For all sites the model predicts higher average values than are measured, with differences from 8 to $40 \mu \mathrm{g} \mathrm{m}{ }^{-3}$. The largest

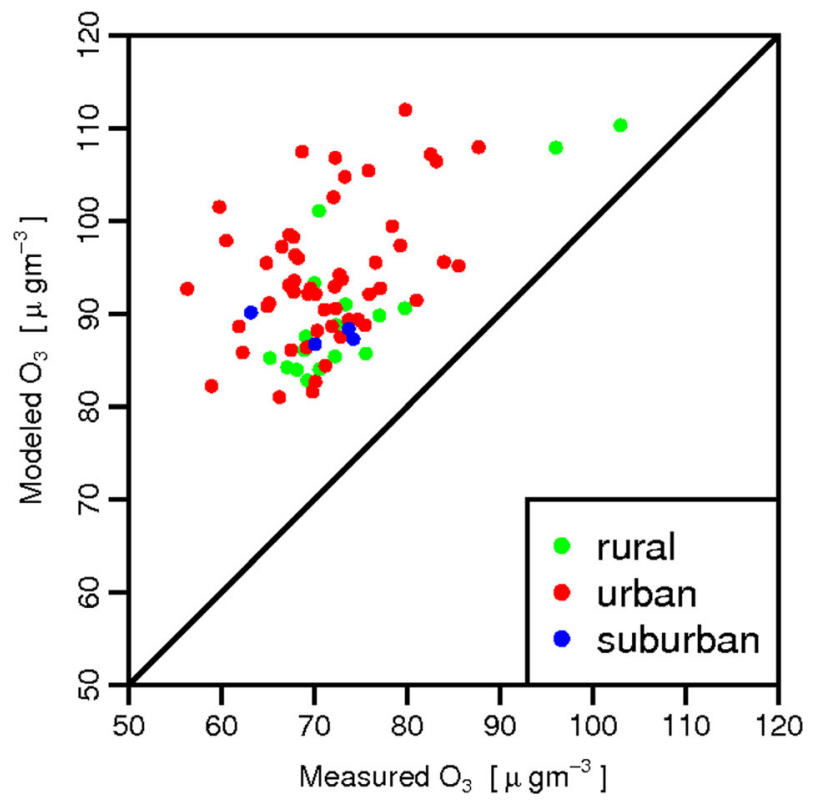

Fig. 3 Measured and modeled $\mathrm{O}_{3}$ concentrations averaged over the study period for each site 
differences are for urban stations, and for majority of rural sites overestimations are lower than $20 \mathrm{~g} \mathrm{~m}^{-3}$. The range of values is also larger for observations (from 56 to $102 \mu \mathrm{g} \mathrm{m}^{-3}$ ) than for model predictions ( 81 to $110 \mu \mathrm{g} \mathrm{m}^{-3}$ ).

To be able to better diagnose prediction errors, it is useful to see how these overestimations change over the study period. An example plot of temporal variability of predicted and measured ozone concentrations for rural (Czerniawa, SW Poland) and urban (Wrocław, also SW Poland) measurement sites are shown in Fig. 4. In general, the model reproduces the peak values well for both urban and rural sites. For urban site the model overestimates low ozone values, although some peak values during the highest ozone days are predicted equal or lower than observed ones (e.g. the beginning of July and the second decade of August). For rural station minimum values are also overpredicted. There is a significant overestimation of a daily minimum on August 17th, when the pollutants were washed out by rainfall. This rainfall event has been predicted by the WRF model, so one possible reason for this overestimation is inaccurate prediction of wet removal rates. The results for other measurement sites present similar patterns (not shown).

Model error statistics are summarized in Table 3 in the appendix. Model results are within model acceptance criteria according to Kumar et al. (1993) regarding FB, FAC2 and NMSE. High NMB and FB values represent systematic errors - overprediction of $\mathrm{O}_{3}$ concentrations, that is dominant in urban locations, which is also why this error statistic has higher value for urban sites. It needs to be indicated that fractional bias value of \pm 0.67 means factor of two
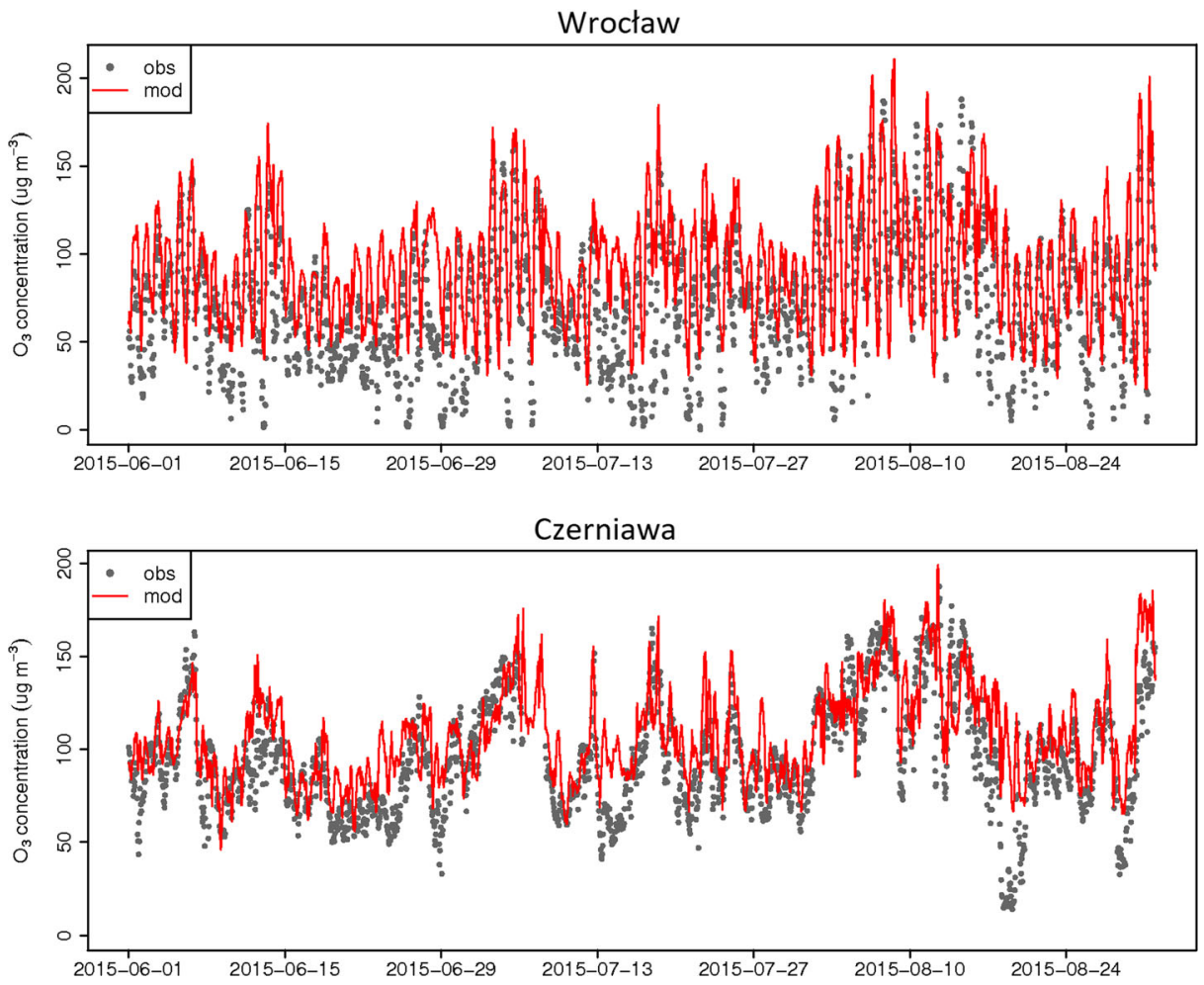

Fig. 4 Measured and modeled hourly $\mathrm{O}_{3}$ concentrations at an urban (top) and rural (bottom) background measurement sites (locations of the stations are presented in Fig. 2) 
Table 3 Model performance statistics. All presented statistics are based on hourly concentrations

\begin{tabular}{|c|c|c|c|}
\hline & All sites & Urban background & Rural background \\
\hline No. of measurements & 166,313 & 114,966 & 38,228 \\
\hline $\mathrm{NMB}[-]$ & 0.29 & 0.32 & 0.22 \\
\hline $\mathrm{FB}[-]$ & -0.25 & -0.27 & -0.19 \\
\hline NMSE $[-]$ & 0.04 & 0.04 & 0.06 \\
\hline MAE $\left[\mu \mathrm{g} \mathrm{m}^{-3}\right]$ & 24.99 & 26.63 & 21.09 \\
\hline $\operatorname{RMSE}\left[\mu \mathrm{g} \mathrm{m}^{-3}\right]$ & 32.20 & 34.02 & 27.66 \\
\hline $\mathrm{FAC} 2[-]$ & 0.84 & 0.82 & 0.86 \\
\hline $\mathrm{d}[-]$ & 0.77 & 0.76 & 0.81 \\
\hline
\end{tabular}

over- or underprediction. NMSE estimates overall deviations between predicted and measured values. It has very low values for both station types, which supports good model performance and indicates small errors for peak values. In this case, NMSE values are higher for rural stations, which suggests larger discrepancies for peaks. Absolute error statistics, MAE and RMSE, also show smaller errors for rural sites. Factor of Two and Index of Agreement also show that the model is fit for purpose, with all FAC2 values above 0.8. Correlation coefficient is more sensitive to outliers than FAC2 and d, hence larger differences between station types. The results show similar performance to modeling studies using various chemical transport models for other regions and different high ozone episodes, e.g. (Chang and Hanna 2004; Ciarelli et al. 2016; Lin et al. 2016; Shen et al. 2011; Solazzo et al. 2012; Vieno et al. 2010; Zhang et al. 2006).

Figure 5 presents model results prepared with Delta Tool. Our results fulfill the MQI criterion $(\mathrm{MQI}<1)$ and all the stations are within acceptable distance from origin. All stations

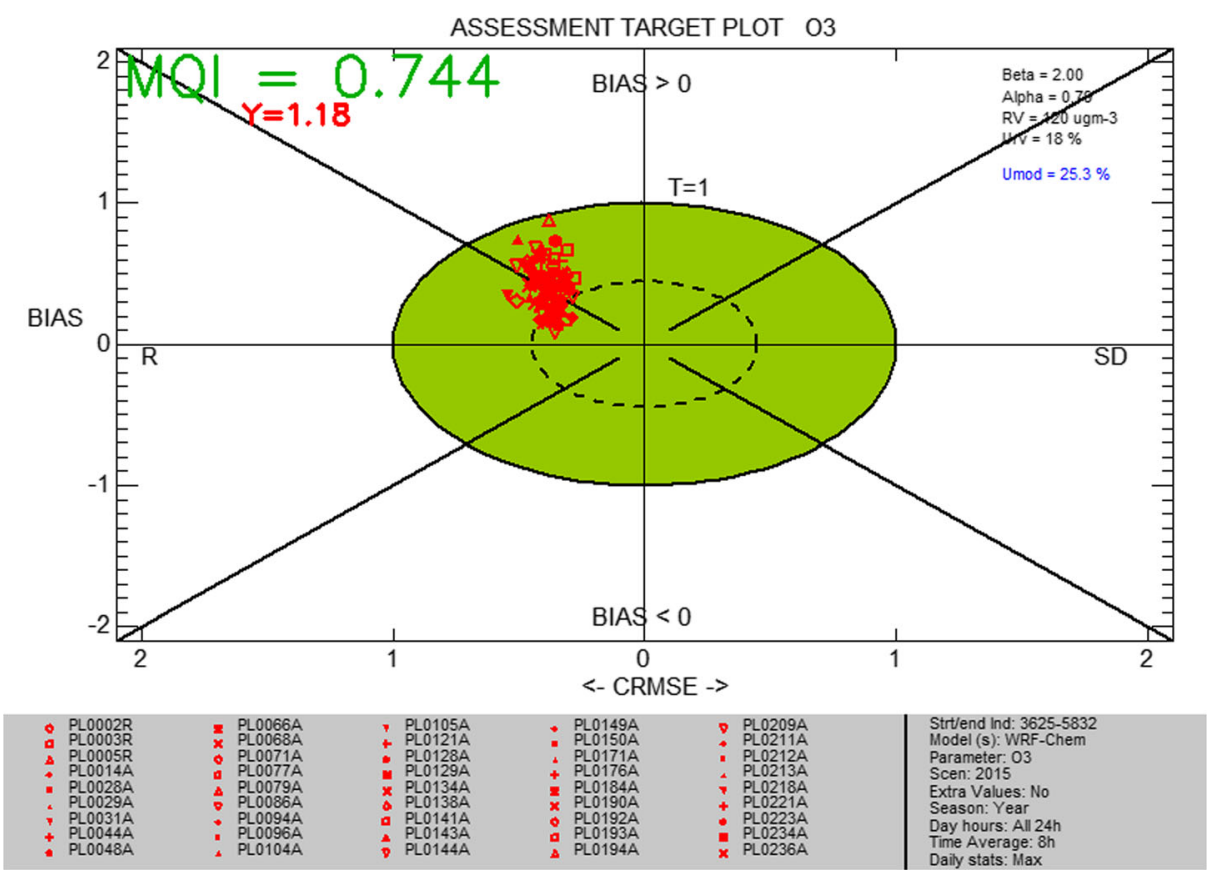

Fig. 5 Delta Tool target plot for 8-h average $\mathrm{O}_{3}$ concentrations at each station 
have positive bias and the error is dominated by the correlation coefficient (all stations in the left quadrant) as opposed to standard deviation. MPC plots (Fig. 6) confirm the dominance of

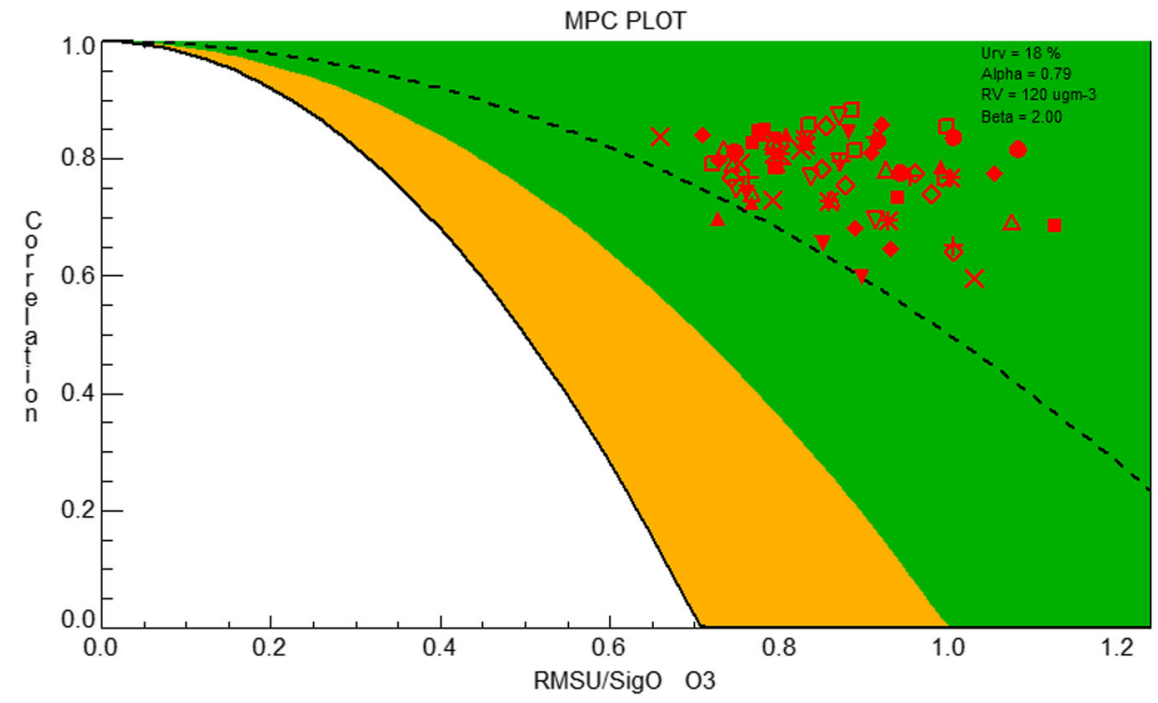

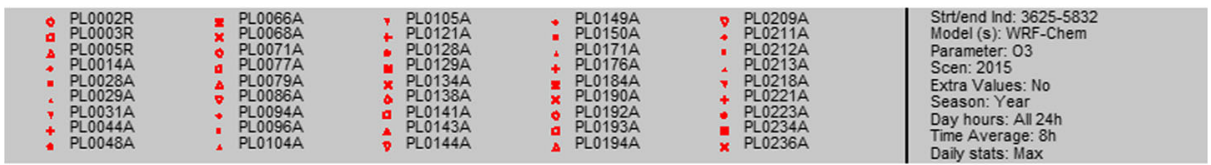

MPC PLOT

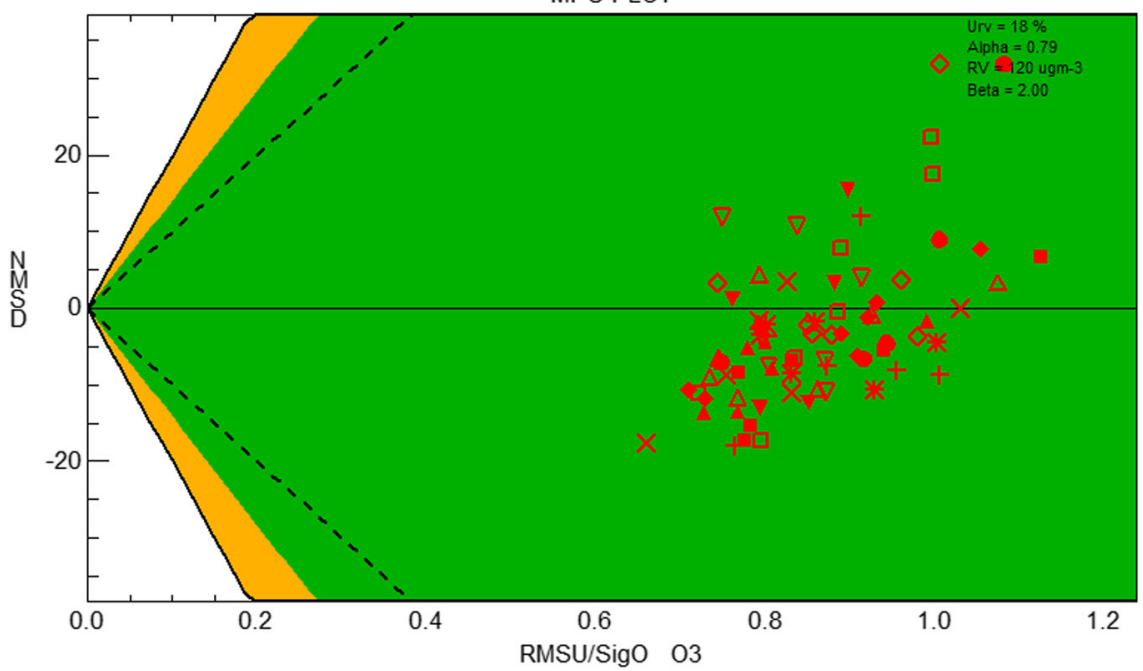

\begin{tabular}{|c|c|c|c|c|c|}
\hline 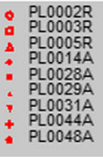 & $\begin{array}{l}\text { PL0066A } \\
\times \text { PL0068A } \\
\text { \& PL0071A } \\
\text { PL0077A } \\
\text { A PL0079A } \\
\text { PL0086A } \\
\text { PL0094A } \\
\text { PL0096A } \\
\text { PL0104A }\end{array}$ & $\begin{array}{l}\text { PL0105A } \\
\text { PL0121A } \\
\text { PL0128A } \\
\text { PL0129A } \\
\text { x PL0134A } \\
\text { \& PL0138A } \\
\text { a PL0141A } \\
\text { A PL0143A } \\
\text { P PL0144A }\end{array}$ & 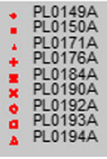 & $\begin{array}{l}\text { PL0209A } \\
\text { PL0211A } \\
\text { PL0212A } \\
\text { PL0213A } \\
\text { * PL0218A } \\
\text { * PL221A } \\
\text { PL0223A } \\
\times \text { PL0234A } \\
\times \text { PL0236A }\end{array}$ & $\begin{array}{l}\text { Strt/end Ind: } 3625-5832 \\
\text { Model (s): WRF-Chem } \\
\text { Parameter: O3 } \\
\text { Scen: } 2015 \\
\text { Extra Values: No } \\
\text { Season: Year } \\
\text { Day hours: All } 24 \mathrm{~h} \\
\text { Time Average: } 8 \mathrm{~h} \\
\text { Daily stats: Max }\end{array}$ \\
\hline
\end{tabular}

Fig. 6 MPC plots for correlation (top) and Normalised Mean Standard Deviation (NMSD, bottom) for 8-h average $\mathrm{O}_{3}$ concentrations at each station 

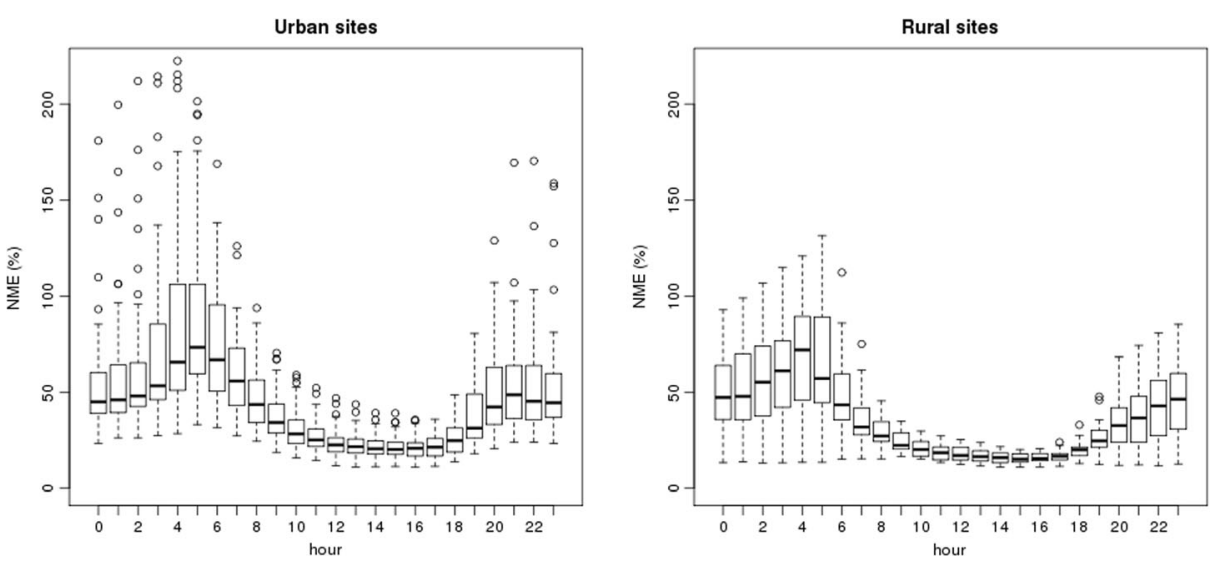

Fig. $7 \mathrm{NME}$ of diurnal variability of $\mathrm{O}_{3}$ concentrations for urban and rural measurement stations, averaged over the study period. The whiskers extend to 1.5 times the interquartile range and hollow circles represent outliers

correlation, although all sites fulfill the $\mathrm{MPC}_{\mathrm{R}}$ criteria. NMSD is also within the range of measurement uncertainty for all measurement sites.

Diurnal variability of Normalized Mean Error of ozone concentrations is presented in Fig. 7. The patterns are similar for urban and rural stations, with the highest overestimations in the morning (4:00-6:00 UTC, with median at 70\% both at urban and rural sites) and evening (21:00-23:00 UTC, median at 50\% at urban and 40-50\% at rural sites) and lowest during the afternoon peak (12:00-17:00 UTC). The range of NME for different measurement sites is also the lowest for peak hours. Model-measurements differences during mornings and evenings are partially caused by the way the model resolves PBL, because vertical mixing is the primary factor determining morning ozone buildup (Zwoździak et al. 2008; Athanassiadis et al. 2002; Lee et al. 2006). This factor is important especially in clear-sky conditions, characteristic for high ozone episodes. Milovac et al. (2016) tested six PBL schemes with the WRF model and showed that all of them failed to account for morning temperature

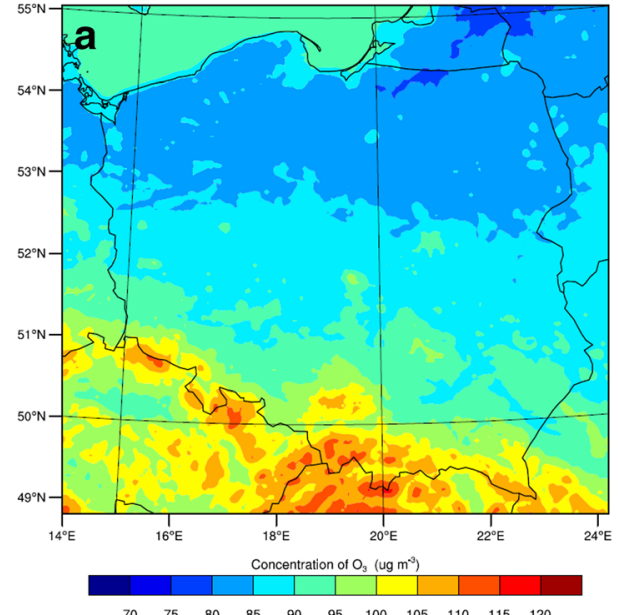

$\begin{array}{lllllllllll}70 & 75 & 80 & 85 & 90 & 95 & 100 & 105 & 110 & 115 & 120\end{array}$

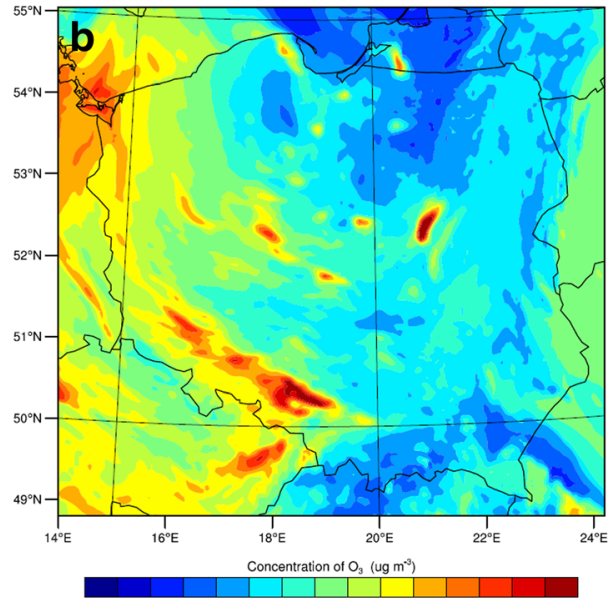

$\begin{array}{llllllllllllll}100 & 110 & 120 & 130 & 140 & 150 & 160 & 170 & 180 & 190 & 200 & 210 & 220 & 230\end{array}$

Fig. $8 \mathrm{O}_{3}$ concentrations (a) averaged over the study period and (b) hourly values on August 7th, 2015, 13 UTC (15 CEST) 


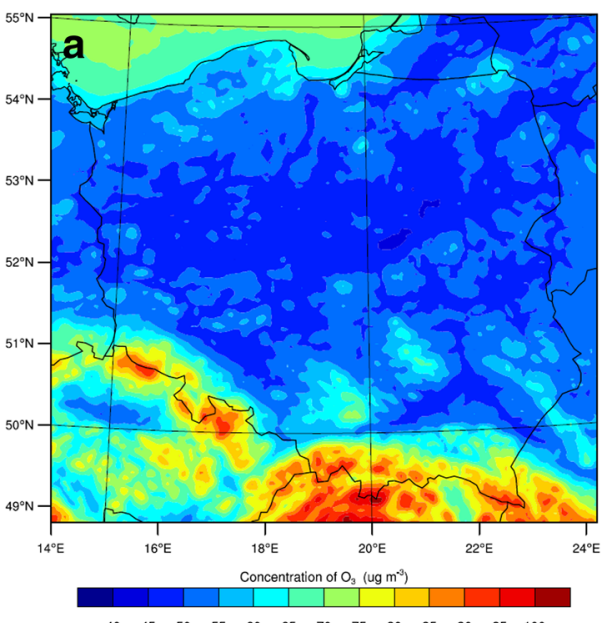

$\begin{array}{lllllllllllll}40 & 45 & 50 & 55 & 60 & 65 & 70 & 75 & 80 & 85 & 90 & 95 & 100\end{array}$

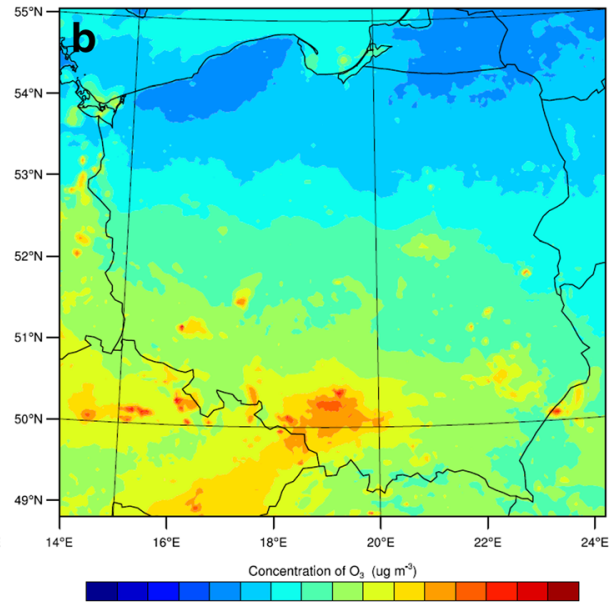

$90 \quad 95100105110115120125130135140145150155160$

Fig. 9 Daily (a) minimum and (b) maximum $\mathrm{O}_{3}$ concentrations averaged over the study period

inversions. Similar errors during morning and evening hours were also reported e.g. for ammonia (Werner et al. 2017). The $\mathrm{NO}_{\mathrm{x}}$ temporal emission profile plays a significant role before and after mid-day equilibrium is achieved and may also enhance these discrepancies. These morning errors also contribute the most to overall model uncertainty, and these processes have the most influence in urban environment, therefore the errors are larger there than at rural sites. Also, the spatial resolution of the model (4 km $\times 4 \mathrm{~km}$ grid) might be insufficient for urban areas with large changes of precursor emissions (Dore et al. 2012), especially for $\mathrm{NO}_{2}$ emission. However, local production also plays some role in rural environment (Im et al. 2013; Dueñas et al. 2004), therefore diurnal patterns there are similar to urban, but with smaller errors in the morning. Because during stable conditions pollutants show distinct vertical profiles, nighttime uncertainties in ozone estimation may be related to vertical model resolution. With first model level reaching PBL height, dry deposition velocity
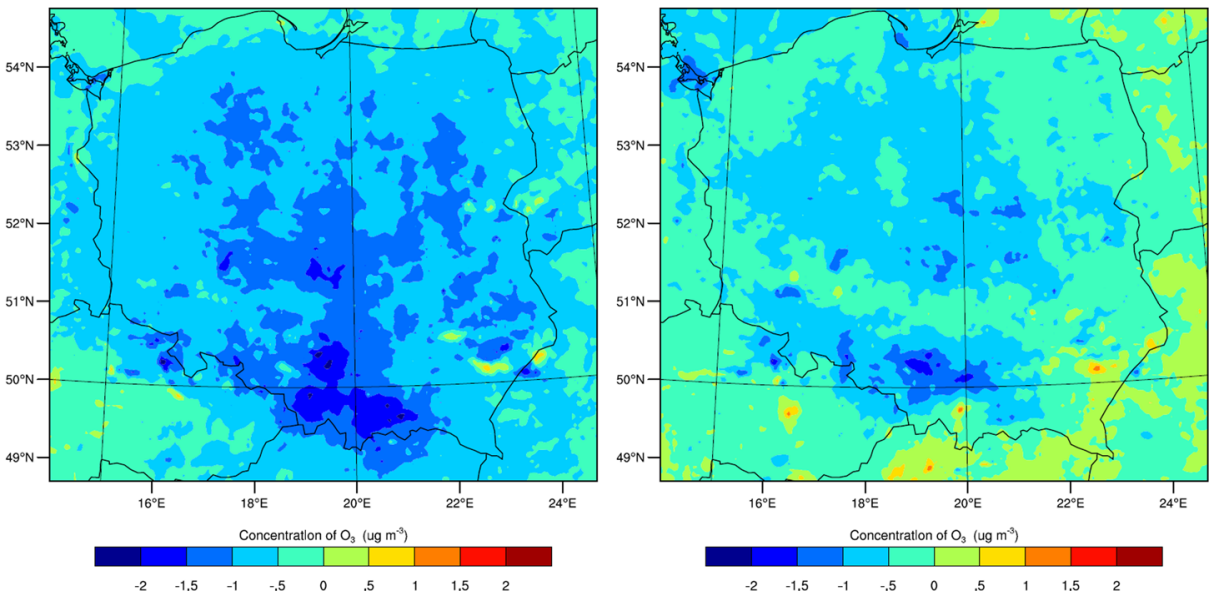

Fig. 10 Differences in $\mathrm{O}_{3}$ concentration averaged over the study period between NOX30 and BASE (left) and VOC30 and BASE simulations (right) 

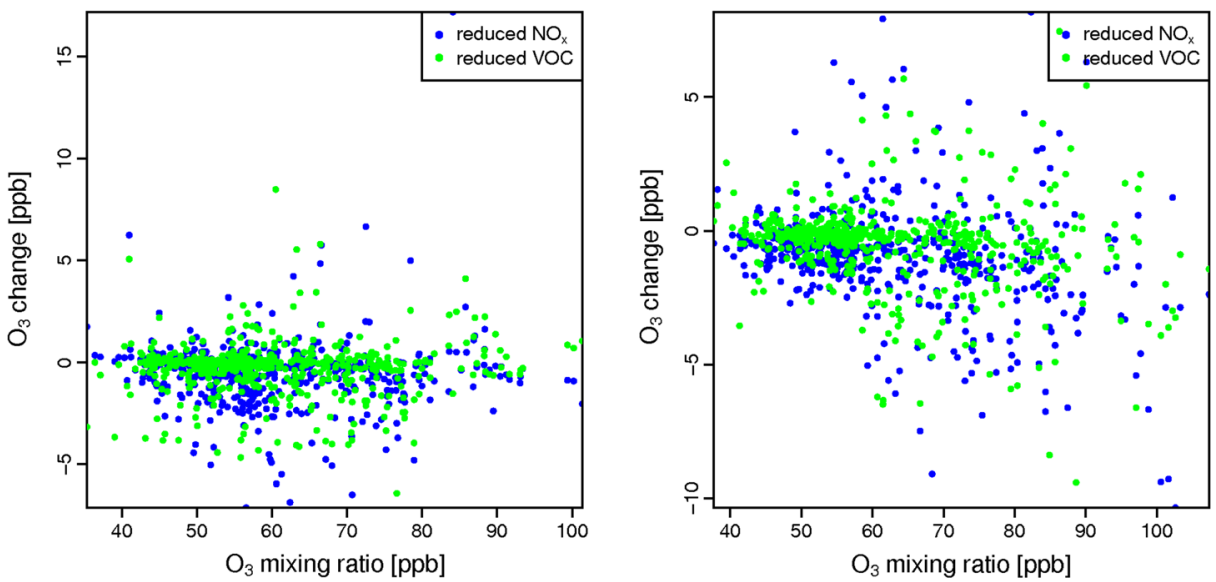

Fig. $11 \Delta \mathrm{O}_{3} / \mathrm{O}_{3}$ ratio for a rural (Czerniawa; left) and urban site (Wrocław; right) for hourly values between 11 and $16 \mathrm{UTC}$

close to the ground is often underestimated (e.g. Stutz et al. 2004; Byun and Dennis 1995). During daytime unstable conditions this effect is not as relevant, because pollutants are wellmixed in the PBL.

\subsection{Emission reduction scenarios}

Modeled spatial distribution of mean ozone concentrations for summer period is shown in Fig. 8a. The highest $\mathrm{O}_{3}$ levels are in Upper Silesia region, Sudetes and Tatra Mountains in the South and the values decrease towards the North. Elevated concentrations in mountainous regions do not reflect exceedance of critical levels regarding human health, because ozone in these regions does not experience diurnal cycle characteristic for in-situ formation, but is a result of regional transport, which causes constantly high ozone levels. These conditions, however, cause exceedance of AOT40 and are detrimental for vegetation. This is also shown
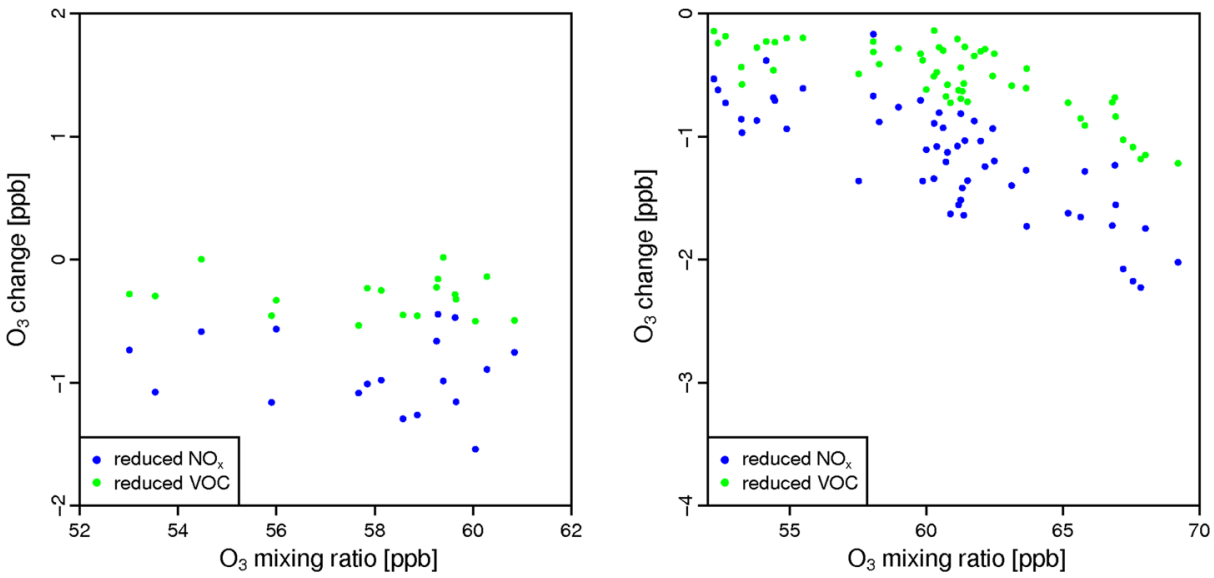

Fig. 12 Mean values of $\Delta \mathrm{O}_{3} / \mathrm{O}_{3}$ ratios for rural (left) and urban site locations (right) for hourly values between 11 and 16 UTC averaged over the entire period 

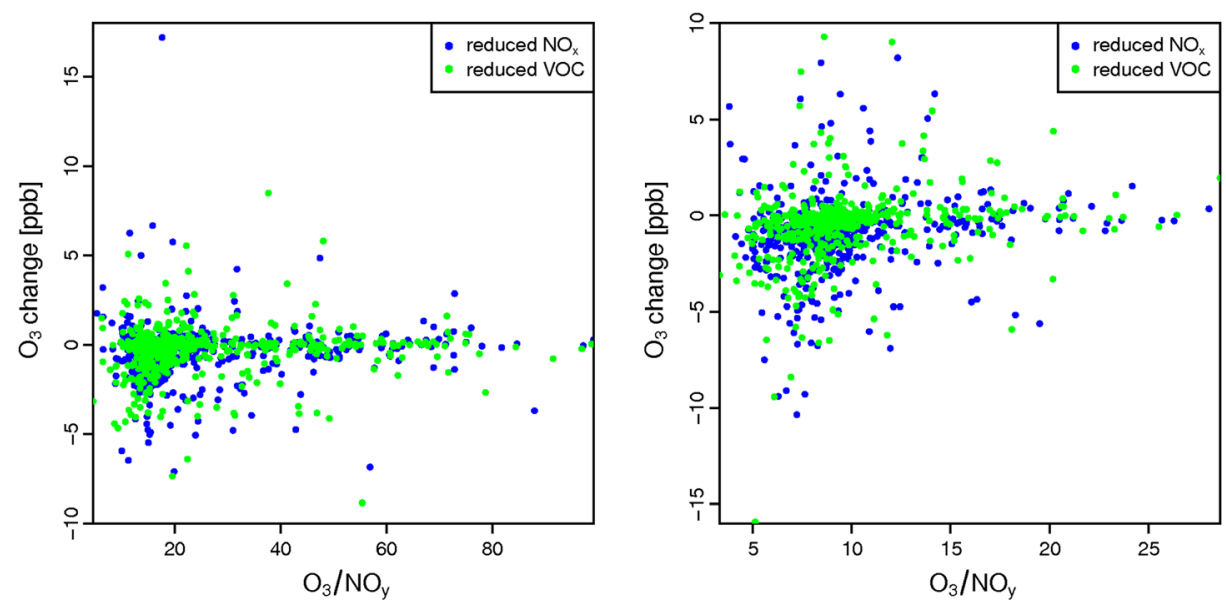

Fig. $13 \mathrm{O}_{3} / \mathrm{NO}_{\mathrm{y}}$ indicator ratio during peak hours rural (Czerniawa; left) and urban (Wrocław; right) measurement station

by high daily minimum concentrations in these areas compared to the rest of the country (Fig. 9a). In lowland urban and suburban environment in-situ formation dominates over regional transport, causing high afternoon peaks and nearly complete disappearance at night. It gives lower average concentrations, but higher average daily maxima, particularly in densely populated Upper Silesia region (Fig. 9b). Figure $8 \mathrm{~b}$ presents $1-\mathrm{h} \mathrm{O}_{3}$ concentrations during a high ozone episode on August 7th, 2015 at 13 UTC. The pattern is entirely different here, with the highest concentrations in south-western and western part of the country, reaching $220 \mu \mathrm{g}$ $\mathrm{m}^{-3}$, with hot spots also in Upper Silesia and in large cities, e.g. Warsaw in central Poland.

Spatial distribution of mean $\mathrm{O}_{3}$ concentration differences between VOC30 and NOX30 and the BASE simulation are presented in Fig. 10. Both maps show a decrease of ozone levels in central Poland, however it is much more pronounced for NOX30-BASE difference. The largest decrease is in south-central part of the country for both emission scenarios $\left(2 \mu \mathrm{g} \mathrm{m}^{-3}\right)$. The area
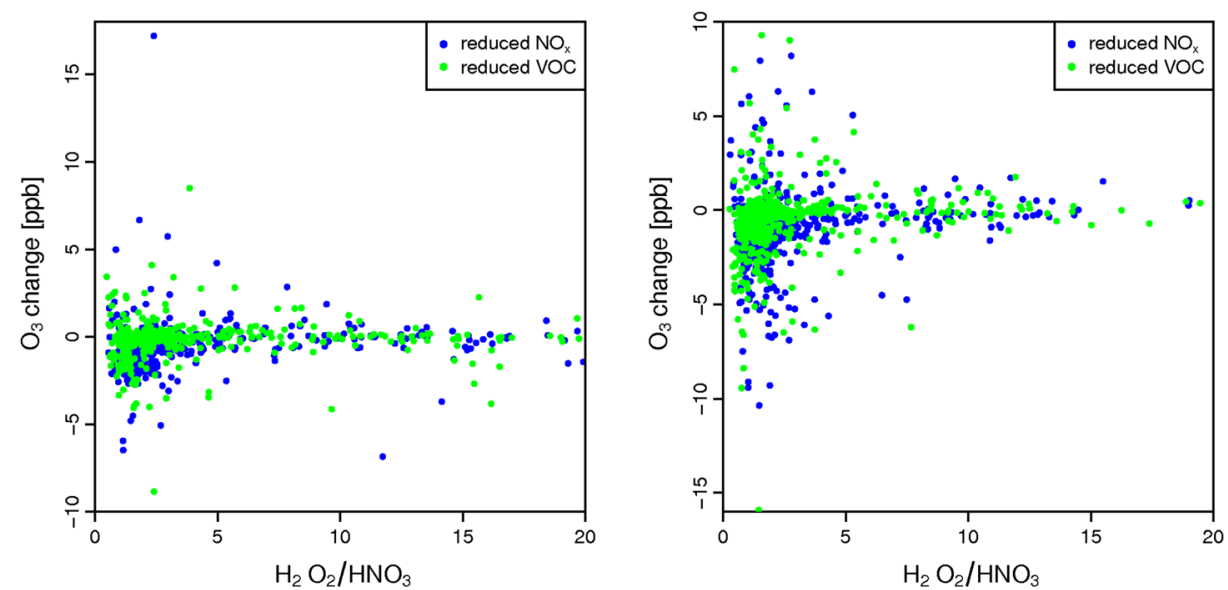

Fig. $14 \mathrm{H}_{2} \mathrm{O}_{2} / \mathrm{HNO}_{3}$ indicator ratio during peak hours for rural (Czerniawa; left) and urban (Wrocław; right) measurement station 

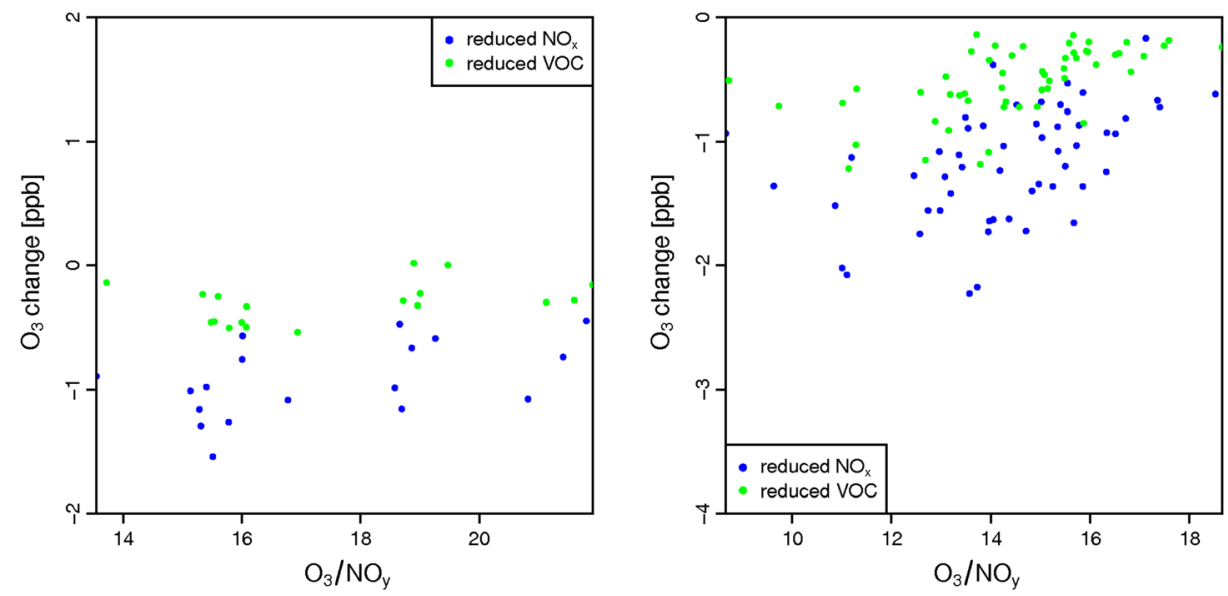

Fig. $15 \mathrm{O}_{3} / \mathrm{NO}_{\mathrm{y}}$ indicator ratio averaged over peak hours for all rural (left) and urban (right) measurement stations

of the largest differences is shifted towards the South because it is a highly urbanized and industrialized area with large anthropogenic emissions, especially $\mathrm{NO}_{\mathrm{x}}$ from transport, but also VOC from chemical industry. The emission was reduced only from the area of Poland, so central part of the country, where transboundary transport of precursors has the smallest influence, also shows larger response to this reduction than regions close to the country borders. Differences are insignificant in the coastal area. This is due to the fact that the emission reduction was applied for land areas only and does not concern emissions from ships, which to a large degree is not under national control.

The response of ozone production to change in precursor emissions can be estimated by the ratio of change in $\mathrm{O}_{3}$ due to emission reduction to ozone mixing ratio for the BASE simulation for that period. The scatterplots of these ratios for selected urban and rural sites are shown in Fig. 11 and average values for all urban and rural site locations in Fig. 12. Although there is no significant relationship between $\mathrm{O}_{3}$ mixing ratio and its change, there is much larger spread in values for the urban site. The results show similar pattern for other measurement sites. $\mathrm{O}_{3}$ changes are larger at urban sites mainly because ozone is formed there from locally emitted
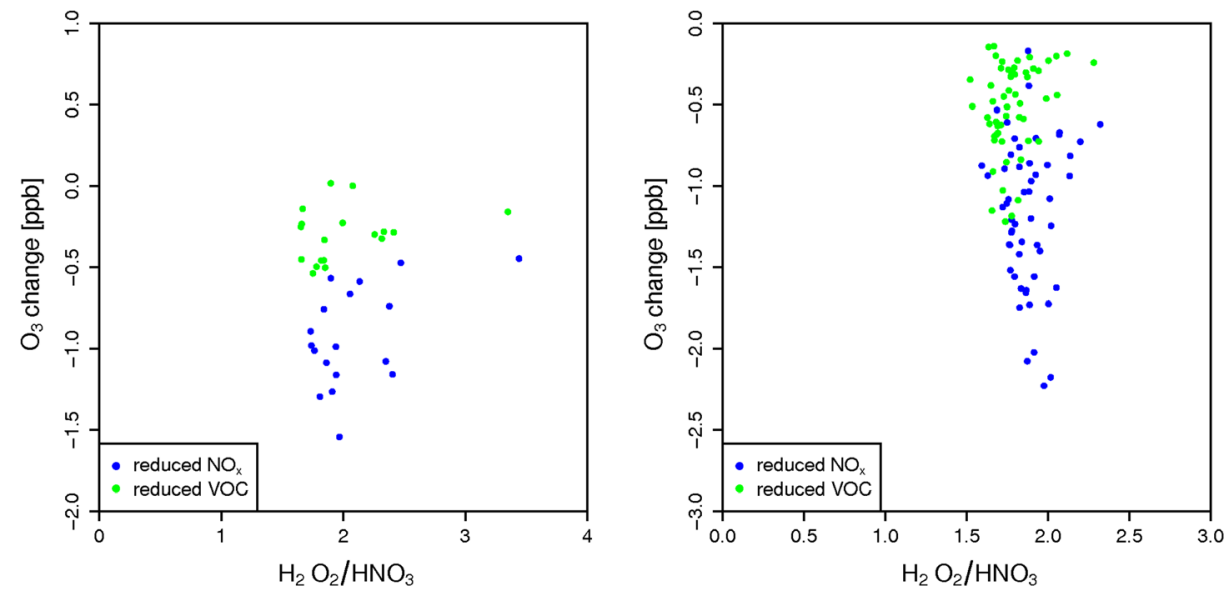

Fig. $16 \mathrm{H}_{2} \mathrm{O}_{2} / \mathrm{HNO}_{3}$ indicator ratio averaged over peak hours for all rural (left) and urban (right) measurement stations 
precursors, which are reduced in both scenarios. At rural sites, there is more influence of regional, also transboundary transport, which is more resistant to changes of precursor emissions. Average values for all sites (Fig. 12) show that both at urban and rural sites a decrease in $\mathrm{O}_{3}$ mixing ratio is larger for NOX30 scenario than VOC30, and the changes increase for high $\mathrm{O}_{3}$ mixing ratios.

To understand the processes responsible for ozone formation, analysis including other chemical species in the form of indicator ratios is done. Figure 13 presents $\mathrm{O}_{3} / \mathrm{NO}_{\mathrm{y}}$ indicator ratios for selected rural and urban sites for ozone peak hours (11-16 UTC). In both cases indicator values are higher than $\mathrm{NO}_{\mathrm{x}}$-sensitivity threshold proposed by Sillman (1995) at 6$8 \mathrm{~mol} / \mathrm{mol}$. However, results are similar for NOX30 and VOC30 scenario, which suggests that presented sites are in mixed sensitivity regime. The same is true for $\mathrm{H}_{2} \mathrm{O}_{2} / \mathrm{HNO}_{3}$ indicator ratio, for which majority of measurement points are in $\mathrm{NO}_{\mathrm{x}}$-sensitive conditions (Fig. 14), according to thresholds established in other European studies (e.g. Andreani-Aksoyoglu and Keller 1997; Castell et al. 2010). These patterns for both indicators are similar for average values for all measurement sites, shown in Fig. 15 and Fig. 16, however with larger decrease in $\mathrm{O}_{3}$ mixing ratios. The results indicate that there is another source of atmospheric hydrogen peroxide other than from $\mathrm{HO}_{2}$ reaction, high $\mathrm{H}_{2} \mathrm{O}_{2} / \mathrm{HNO}_{3}$ indicator ratios may also be a result of the VOCs reactivity. High $\mathrm{O}_{3} / \mathrm{NO}_{\mathrm{y}}$ values may indicate losses of reactive nitrogen due to reactions with aerosols or wet deposition.

\section{Conclusions}

In this work, an ozone modelling study has been conducted for the area of Poland, which included statistical evaluation of the WRF-Chem model results for summer 2015 and analysis of the role of precursor emissions on ambient ozone concentrations with the use of indicator ratios.

Model evaluation includes diurnal variations in model performance, to reflect ozone daily cycle, as well as regional patterns and distinction between urban and rural background stations. The model overestimates both peak values and minima, which affects the estimation of critical levels exceedance by the model. However, the largest errors are observed in the morning and evening, mostly due to uncertainties in PBL height and, consequently, vertical mixing in the mixing layer, and afternoon peak hours present lower overestimations. Despite the differences in diurnal ozone variations between urban and rural background stations, the patterns of NME are similar, although at rural sites the magnitude of errors is smaller by approximately $10 \mu \mathrm{g}$ $\mathrm{m}^{-3}$. This suggests that uncertainties in parameterization of in situ ozone production rates constitute a significant part of overall ozone concentration uncertainty in both urban and rural environments.

Model performance differs between urban and rural sites. Errors are larger for urban stations, which indicates issues in ozone formation mechanisms in urban conditions or uncertainties in spatial representation of $\mathrm{O}_{3}$ precursor emissions, primarily $\mathrm{NO}_{\mathrm{x}}$ from transport and biogenic emissions of VOC, which have very short atmospheric lifetimes and their emissions depend on tree species and meteorological conditions. These uncertainties include both emission totals and their spatial and temporal distribution. PBL also plays a role, as it determines dispersion of pollutants within the mixing layer. Other European studies show that urban ozone is predominantly a result of local ozone formation (Stevenson et al. 2006), which suggests that larger uncertainties in this environment are also a result of local chemistry. 
Model errors are predominantly systematic and are most likely a result of chemical mechanisms and meteorological fields, i.e. cloud cover and wind speed, both of which greatly affect ozone formation processes and have usually large uncertainties (Wałaszek et al. 2016; Wałaszek et al. 2014a). Some overestimations may also result from missed or shifted rainfall events (Kryza et al. 2013). Other possible uncertainty sources include initial and boundary conditions (including background ozone levels), inaccurate land use and LAI information and PBL parameterization. Land use and LAI are particularly important for biogenic emission model and affect modelled VOC emissions from natural sources (Gulden et al. 2007; Simpson et al. 1995).

Both modelled and measured ozone shows a clear diurnal cycle at urban sites for the entire study period, and the observed cycle is well reproduced by the model. Temporal variability of ozone at urban sites shows that conditions were favorable for ozone formation in Poland throughout the summer, and especially during the first half of August, when critical levels were exceeded. At rural sites, on the other hand, neither daily cycle nor critical levels exceedances are observed, but $\mathrm{O}_{3}$ concentrations are constantly above hemispheric background level of approxw. 40-70 $\mathrm{g} \mathrm{m} \mathrm{m}^{-3}$ (Vingarzan 2004). This can be attributed to both long range and regional transport of ozone from polluted regions, as well as ozone descending from the stratosphere, characteristic for spring and summer season in midlatitudes (Hsu 2005; Husain et al. 1977). Other studies regarding ozone patterns in urban and rural environments in Europe also suggest dominant role of regional transport at rural sites (Dueñas et al. 2004; FernándezGuisuraga et al. 2016; Im et al. 2013).

Analysis of the changes in ozone mixing ratios and indicator ratios suggests that for majority of Poland ozone production regime shows mixed sensitivity to emissions of precursors, but with slightly better response to $\mathrm{NO}_{x}$ reduction. Average $\mathrm{O}_{3}$ changes resulting from precursor emissions reduction presented in this study are consistent with other studies for summer period. A research conducted for the whole Europe for July 2007 (Mar et al. 2016) shows the same sensitivity patterns, i.e. mixed sensitivity to emissions of precursors. Discrepancies between literature threshold values for $\mathrm{NO}_{\mathrm{x}}$-sensitive and $\mathrm{VOC}$-sensitive regime and the ones presented in this study (two times higher than $\mathrm{NO}_{\mathrm{x}}$-sensitivity threshold proposed by (Jacob et al. 1995; Sillman 1995) support a conclusion that these threshold values can significantly differ between locations, and also between episodes for the same location (Castell et al. 2010). It is important for threshold values to be determined individually for each case and to establish transition values characteristic for a given study area.

Photochemical indicators are potentially a good method of estimating how further reductions would influence ozone concentrations, however they suffer from large variations in transition values and need to be supported with field measurements of all of their components. Measurements of ozone-related species other than $\mathrm{NO}_{\mathrm{x}}$ are very sparse in Poland and it would require a dedicated measurement campaign. This combined with isopleth diagrams based on multiple model simulations with different precursor reductions would give better understanding of summertime ozone formation conditions in Poland. This study suggests that anthropogenic emission has large influence on ozone concentrations. Both $\mathrm{NO}_{\mathrm{x}}$ and $\mathrm{VOC}$ emission control would be beneficial for air quality and would lower the risk and frequency of high ozone episodes during summer, in particular in central and southern parts of the country. For future work, it would also be interesting to examine the role of emission reduction in individual SNAP sectors (e.g. road transport; Suppan and Schädler 2004) on both regional and urban air quality and take into account the "weekend effect", which has been reported to have impact on ozone concentrations in urban areas in Europe (Pires 2012). 
Acknowledgements The study was supported by the Polish National Science Centre project no. UMO-2013/ 09/B/ST10/00594.

Open Access This article is distributed under the terms of the Creative Commons Attribution 4.0 International License (http://creativecommons.org/licenses/by/4.0/), which permits unrestricted use, distribution, and reproduction in any medium, provided you give appropriate credit to the original author(s) and the source, provide a link to the Creative Commons license, and indicate if changes were made.

\section{References}

Aksoyoglu, S., Keller, J., Oderbolz, D.C., Barmpadimos, I., Prévôt, A.S.H., Baltensperger, U.: Sensitivity of ozone and aerosols to precursor emissions in Europe. Int. J. Environ. Pollut. 50(1), 451-459 (2012)

Alapaty, K., Niyogi, D., Chen, F., Pyle, P., Chandrasekar, A., Seaman, N.: Development of the flux-adjusting surface data assimilation system for mesoscale models. J. Appl. Meteorol. Climatol. 47(9), 2331-2350 (2008)

Andreani-Aksoyoglu, S., Keller, J.: Indicator species for $\mathrm{O}_{3}$, sensitivity relative to $\mathrm{NO}_{\mathrm{x}}$ and $\mathrm{VOC}$ in Switzerland and their dependence on meteorology. WIT Trans Ecol Environ. 21, (1997). https://doi.org/10.2495/AIR970851

Athanassiadis, G.A., Rao, S.T., Ku, J.-Y., Clark, R.D.: Boundary Layer Evolution and its Influence on GroundLevel Ozone Concentrations. Environ. Fluid Mech. 2(4), 339-357 (2002)

Bieser, J., Aulinger, A., Matthias, V., Quante, M., Denier van der Gon, H.A.C.: Vertical emission profiles for Europe based on plume rise calculations. Environ. Pollut. 159(10), 2935-2946 (2011)

Biswas, J., Rao, S.T.: Uncertainties in episodic ozone modeling stemming from uncertainties in the meteorological fields. J. Appl. Meteorol. 40(2), 117-136 (2001)

Borrego, C., Tchepel, O., Monteiro, A., Barros, N., Miranda, A.: Influence of traffic emissions estimation variability on urban air quality modelling. Water Air Soil Pollut. Focus. 2(5), 487-499 (2002)

Byun, D.W., Dennis, R.: Design artifacts in eulerian air quality models: Evaluation of the effects of layer thickness and vertical profile correction on surface ozone concentrations. Atmos. Environ. 29(1), 105-126 (1995)

Campbell, P., Zhang, Y., Yahya, K., Wang, K., Hogrefe, C., Pouliot, G., Knote, C., Hodzic, A., San Jose, R., Perez, J.L., Jimenez-Guerrero, P., Baro, R., Makar, P.: A multi-model assessment for the 2006 and 2010 simulations under the Air Quality Model Evaluation International Initiative (AQMEII) phase 2 over North America: Part I. Indicators of the sensitivity of O3 and PM2.5 formation regimes. Atmos. Environ. 115, 569-586 (2015)

Carslaw, D.C., Ropkins, K.: Openair - An r package for air quality data analysis. Environ. Model. Softw. 27-28, 52-61 (2012)

Castell, N., Stein, A.F., Mantilla, E., Salvador, R., Millán, M.: Evaluation of the use of photochemical indicators to assess ozone-NOx-VOC sensitivity in the Southwestern Iberian Peninsula. J. Atmos. Chem. 63(1), 73-91 (2010)

Chang, J.C., Hanna, S.R.: Air quality model performance evaluation. Meteorog. Atmos. Phys. 87(1-3), 167-196 (2004)

Chock, D.P., Chang, T.Y., Winkler, S.L., Nance, B.I.: The impact of an 8 h ozone air quality standard on ROG and NOx controls in Southern California. Atmos. Environ. 33(16), 2471-2485 (1999)

Ciarelli, G., Aksoyoglu, S., Crippa, M., Jimenez, J.-L., Nemitz, E., Sellegri, K., Äijälä, M., Carbone, S., Mohr, C., O’Dowd, C., Poulain, L., Baltensperger, U., Prévôt, A.S.H.: Evaluation of European air quality modelled by CAMx including the volatility basis set scheme. Atmos. Chem. Phys. 16(16), 10313-10332 (2016)

Dębski, B., Olecka, A., Bebkiewicz, K., Kargulewicz, I., Rutkowski, J., Zasina, D., Zimakowska-Laskowska, M., Żaczek, M.: Poland's Informative Inventory Report 2016. Warszawa (2016). Retrieved from http://www. kobize.pl/uploads/materialy/materialy_do_pobrania/krajowa_inwentaryzacja_emisji/IIR_Poland_2016.pdf

Dore, A.J., Kryza, M., Hall, J.R., Hallsworth, S., Keller, V.J.D., Vieno, M., Sutton, M.A.: The influence of model grid resolution on estimation of national scale nitrogen deposition and exceedance of critical loads. Biogeosciences. 9, 1597-1609 (2012). https://doi.org/10.5194/bg-9-1597-2012

Dueñas, C., Fernández, M.C., Cañete, S., Carretero, J., Liger, E.: Analyses of ozone in urban and rural sites in Málaga (Spain). Chemosphere. 56(6), 631-639 (2004)

Emmons, L.K., Walters, S., Hess, P.G., Lamarque, J.-F., Pfister, G.G., Fillmore, D., Granier, C., Guenther, A., Kinnison, D., Laepple, T., Orlando, J., Tie, X., Tyndall, G., Wiedinmyer, C., Baughcum, S.L., Kloster, S.: Description and evaluation of the Model for Ozone and Related chemical Tracers, version 4 (MOZART-4). Geosci. Model Dev. 3(1), 43-67 (2010)

Fernández-Guisuraga, J.M., Castro, A., Alves, C., Calvo, A., Alonso-Blanco, E., Blanco-Alegre, C., Rocha, A., Fraile, R.: Nitrogen oxides and ozone in Portugal: trends and ozone estimation in an urban and a rural site. Environ. Sci. Pollut. Res. 23(17), 17171-17182 (2016)

Friedrich, R., Reis, S.: Emissions of Air Pollutants: Measurements, Calculations and Uncertainties. SpringerVerlag Berlin, Heidelberg (2004). https://doi.org/10.1007/978-3-662-07015-4 
Gong, S.L.: A parameterization of sea-salt aerosol source function for sub- and super-micron particles. Glob Biogeochem. Cycles. 17, 1097 (2003). https://doi.org/10.1029/2003GB002079

Guenther, A., Hewitt, C.N., Erickson, D., Fall, R., Geron, C., Graedel, T., Harley, P., Klinger, L., Lerdau, M., Mckay, W.A., Pierce, T., Scholes, B., Steinbrecher, R., Tallamraju, R., Taylor, J., Zimmerman, P.: A global model of natural volatile organic compound emissions. J. Geophys. Res. 100(D5), 8873 (1995)

Guenther, A., Karl, T., Harley, P., Wiedinmyer, C., Palmer, P.I., Geron, C.: Estimates of global terrestrial isoprene emissions using MEGAN (Model of Emissions of Gases and Aerosols from Nature). Atmos. Chem. Phys. 6(11), 3181-3210 (2006)

Gulden, L.E., Yang, Z.-L., Niu, G.-Y.: Interannual variation in biogenic emissions on a regional scale. J. Geophys. Res. 112(D14), D14103 (2007)

Holnicki, P., Nahorski, Z.: Emission Data Uncertainty in Urban Air Quality Modeling - Case Study. Environ. Model. Assess. 20(6), 583-597 (2015)

Hsu, J.: Diagnosing the stratosphere-to-troposphere flux of ozone in a chemistry transport model. J. Geophys. Res. 110(D19), D19305 (2005)

Husain, L., Coffey, P.E., Meyers, R.E., Cederwall, R.T.: Ozone transport from stratosphere to troposphere. Geophys. Res. Lett. 4(9), 363-365 (1977)

Iacono, M.J., Delamere, J.S., Mlawer, E.J., Shephard, M.W., Clough, S.A., Collins, W.D.: Radiative forcing by long-lived greenhouse gases: Calculations with the AER radiative transfer models. J. Geophys. Res.Atmos. 113(D13), D13103 (2008)

Im, U., Incecik, S., Guler, M., Tek, A., Topcu, S., Unal, Y.S., Yenigun, O., Kindap, T., Odman, M.T., Tayanc, M.: Analysis of surface ozone and nitrogen oxides at urban, semi-rural and rural sites in Istanbul, Turkey. Sci. Total Environ. 443, 920-931 (2013)

Jacob, D.J., Horowitz, L.W., Munger, J.W., Heikes, B.G., Dickerson, R.R., Artz, R.S., Keene, W.C.: Seasonal transition from NOx- to hydrocarbon-limited conditions for ozone production over the eastern United States in September. J. Geophys. Res. 100(D5), 9315 (1995)

Kleinman, L.I.: The dependence of tropospheric ozone production rate on ozone precursors. Atmos. Environ. 39(3), 575-586 (2005)

Konovalov, I.B.: Application of neural networks for studying nonlinear relationships between ozone and its precursors. J. Geophys. Res.Atmos. 107(D11), ACH 8-1-ACH 8-14 (2002)

Kryza, M., Werner, M., Wałaszek, K., Dore, A.J.: Application and evaluation of the WRF model for highresolution forecasting of rainfall - a case study of SW Poland. Meteorol. Z. 22(5), 595-601 (2013)

Kuenen, J.J.P., Visschedijk, A.J.H., Jozwicka, M., Denier van der Gon, H.A.C.: TNO-MACC II emission inventory: a multi-year (2003-2009) consistent high-resolution European emission inventory for air quality modelling. Atmos. Chem. Phys. 14(20), 10963-10976 (2014)

Kumar, A., Luo, J., Bennett, G.F.: Statistical evaluation of Lower Flammability Distance(LFD) using four hazardous release models. Process. Saf. Prog. 12(1), 1-11 (1993)

Lee, J.D., Lewis, A.C., Monks, P.S., Jacob, M., Hamilton, J.F., Hopkins, J.R., Watson, N.M., Saxton, J.E., Ennis, C., Carpenter, L.J., Carslaw, N., Fleming, Z., Bandy, B.J., Oram, D.E., Penkett, S.A., Slemr, J., Norton, E., Rickard, A.R., Whalley, L., Heard, D.E., Bloss, W.J., Gravestock, T., Smith, S.C., Stanton, J., Pilling, M.J., Jenkin, M.E.: Ozone photochemistry and elevated isoprene during the UK heatwave of august 2003. Atmos. Environ. 40(39), 7598-7613 (2006)

Lee, S.-B., Bae, G.-N., Moon, K.-C.: Smog Chamber Measurements BT - Atmospheric and Biological Environmental Monitoring. In: Y. J. Kim, U. Platt, M. B. Gu, \& H. Iwahashi (eds.) pp. 105-136. Springer Netherlands (2009). https://doi.org/10.1007/978-1-4020-9674-7_8

Liang, J., Jackson, B., Kaduwela, A.: Evaluation of the ability of indicator species ratios to determine the sensitivity of ozone to reductions in emissions of volatile organic compounds and oxides of nitrogen in northern California. Atmos. Environ. 40(27), 5156-5166 (2006)

Lin, C., Heal, M.R., Vieno, M., MacKenzie, I.A., Armstrong, B.G., Butland, B.K., Milojevic, A., Chalabi, Z., Atkinson, R.W., Stevenson, D.S., Doherty, R.M., Wilkinson, P.: Spatiotemporal evaluation of EMEP4UKWRF v4.3 atmospheric chemistry transport simulations of health-related metrics for NO2, O3, PM10 and PM2.5 for 2001-2010. Geosci. Model Dev. Discuss. 1-28, (2016)

Mallet, V., Sportisse, B.: Uncertainty in a chemistry-transport model due to physical parameterizations and numerical approximations: An ensemble approach applied to ozone modeling. J. Geophys. Res. 111(D1), D01302 (2006)

Mar, K.A., Ojha, N., Pozzer, A., Butler, T.M.: Ozone air quality simulations with WRF-Chem (v3.5.1) over Europe: model evaluation and chemical mechanism comparison. Geosci. Model Dev. 9(10), 3699-3728 (2016)

Milford, J.B., Gao, D., Sillman, S., Blossey, P., Russell, A.G.: Total reactive nitrogen (NOy) as an indicator of the sensitivity of ozone to reductions in hydrocarbon and NOx emissions. J. Geophys. Res.Atmos. 99(D2), 3533-3542 (1994) 
Milovac, J., Warrach-Sagi, K., Behrendt, A., Späth, F., Ingwersen, J., Wulfmeyer, V.: Investigation of PBL schemes combining the WRF model simulations with scanning water vapor differential absorption lidar measurements. J. Geophys. Res. Atmos. 121, 624-649 (2016). https://doi.org/10.1002/2015JD023927

Morrison, H., Thompson, G., Tatarskii, V.: Impact of Cloud Microphysics on the Development of Trailing Stratiform Precipitation in a Simulated Squall Line: Comparison of One- and Two-Moment Schemes. Mon. Weather Rev. 137(3), 991-1007 (2009)

Peng, Y.P., Chen, K.S., Wang, H.-K., Lee, C.-H.: Applying model simulation and photochemical indicators to evaluate ozone sensitivity in southern Taiwan. J. Environ. Sci. 23(5), 790-797 (2011)

Pierce, T., Geron, C., Bender, L., Dennis, R., Tonnesen, G., Guenther, A.: Influence of increased isoprene emissions on regional ozone modeling. J. Geophys. Res.Atmos. 103(D19), 25611-25629 (1998)

Pires, J.C.M.: Ozone Weekend Effect Analysis in Three European Urban Areas. CLEAN. 40(8), 790-797 (2012)

Russell, A., Dennis, R.: NARSTO critical review of photochemical models and modeling. Atmos. Environ. 34, 2283-2324 (2000)

Shen, J., Wang, X., Li, J., Li, Y., Zhang, Y.: Evaluation and intercomparison of ozone simulations by Models-3/ CMAQ and CAMx over the Pearl River Delta. Sci. China Chem. 54(11), 1789-1800 (2011)

Sierra, A., Vanoye, A.Y., Mendoza, A.: Ozone sensitivity to its precursor emissions in northeastern Mexico for a summer air pollution episode. J. Air Waste Manage. Assoc. 63(10), 1221-1233 (2013)

Sillman, S.: The use of NOy, H2O2, and HNO3 as indicators for ozone-NOx-hydrocarbon sensitivity in urban locations. J. Geophys. Res. 100(D7), 14175 (1995)

Sillman, S.: The relation between ozone, NOx and hydrocarbons in urban and polluted rural environments. Atmos. Environ. 33(12), 1821-1845 (1999a)

Sillman, S.: The erroneous use of receptor modeling to diagnose O3-NO(x)-hydrocarbon sensitivity. Atmos. Environ. 33(14), 2289-2291 (1999b)

Sillman, S., He, D.: Some theoretical results concerning O3-NOx-VOC chemistry and NOx -VOC indicators. J. Geophys. Res. 107(D22), 4659 (2002)

Sillman, S., He, D., Pippin, M.R., Daum, P.H., Imre, D.G., Kleinman, L.I., Lee, J.H., Weinstein-Lloyd, J.: Model correlations for ozone, reactive nitrogen, and peroxides for Nashville in comparison with measurements: Implications for O3-NOx-hydrocarbon chemistry. J. Geophys. Res.Atmos. 103(D17), 22629-22644 (1998)

Simpson, D., Guenther, A., Hewitt, C.N., Steinbrecher, R.: Biogenic emissions in Europe: 1. Estimates and uncertainties. J. Geophys. Res.Atmos. 100(D11), 22875-22890 (1995)

Solazzo, E., Bianconi, R., Vautard, R., Appel, K.W., Moran, M.D., Hogrefe, C., Bessagnet, B., Brandt, J., Christensen, J.H., Chemel, C., Coll, I., Denier van der Gon, H.A.C., Ferreira, J., Forkel, R., Francis, X.V., Grell, G., Grossi, P., Hansen, A.B., Jeričević, A., Kraljević, L., Miranda, A.I., Nopmongcol, U., Pirovano, G., Prank, M., Riccio, A., Sartelet, K.N., Schaap, M., Silver, J.D., Sokhi, R.S., Vira, J., Werhahn, J., Wolke, R., Yarwood, G., Zhang, J., Rao, S.T., Galmarini, S.: Model evaluation and ensemble modelling of surface-level ozone in Europe and North America in the context of AQMEII. Atmos. Environ. 53, 60-74 (2012)

Spirig, C., Neftel, A., Kleinman, L.I., Hjorth, J.: NOx versus VOC limitation of O3 production in the Po valley: Local and integrated view based on observations. J. Geophys. Res.Atmos. 107(D22), 8191 (2002)

Stevenson, D.S., Dentener, F.J., Schultz, M.G., Ellingsen, K., van Noije, T.P.C., Wild, O., Zeng, G., Amann, M., Atherton, C.S., Bell, N., Bergmann, D.J., Bey, I., Butler, T., Cofala, J., Collins, W.J., Derwent, R.G., Doherty, R.M., Drevet, J., Eskes, H.J., Fiore, A.M., Gauss, M., Hauglustaine, D.A., Horowitz, L.W., Isaksen, I.S.A., Krol, M.C., Lamarque, J.-F., Lawrence, M.G., Montanaro, V., Müller, J.-F., Pitari, G., Prather, M.J., Pyle, J.A., Rast, S., Rodriguez, J.M., Sanderson, M.G., Savage, N.H., Shindell, D.T., Strahan, S.E., Sudo, K., Szopa, S.: Multimodel ensemble simulations of present-day and near-future tropospheric ozone. J. Geophys. Res. 111(D8), D08301 (2006)

Stutz, J., Alicke, B., Ackermann, R., Geyer, A., White, A., Williams, E.: Vertical profiles of NO3, N2O5, O3, and NOx in the nocturnal boundary layer: 1. Observations during the Texas Air Quality Study 2000. J. Geophys. Res.Atmos. 109(12), 1-15 (2004)

Suppan, P., Schädler, G.: The impact of highway emissions on ozone and nitrogen oxide levels during specific meteorological conditions. Sci. Total Environ. 334-335, 215-222 (2004)

Thunis, P., Pederzoli, A., Pernigotti, D.: Performance criteria to evaluate air quality modeling applications. Atmos. Environ. 59, 476-482 (2012)

Thunis, P., Pernigotti, D., Gerboles, M.: Model quality objectives based on measurement uncertainty. Part I: Ozone. Atmos. Environ. 79, 861-868 (2013)

Thunis, P., Cuvelier, C., Pederzoli, A., Georgieva, E., Pernigotti, D., Degraeuwe, B., Marioni, M.: DELTA Version 5.4 Concepts / User's Guide / Diagrams. (2016). Retrieved from http://fairmode.jrc.ec.europa. eu/document/fairmode/WG1/DELTA_UserGuide_V5_1.pdf

van Loon, M., Vautard, R., Schaap, M., Bergström, R., Bessagnet, B., Brandt, J., Builtjes, P.J.H., Christensen, J.H., Cuvelier, C., Graff, A., Jonson, J.E., Krol, M., Langner, J., Roberts, P., Rouil, L., Stern, R., Tarrasón, L., 
Thunis, P., Vignati, E., White, L., Wind, P.: Evaluation of long-term ozone simulations from seven regional air quality models and their ensemble. Atmos. Environ. 41(10), 2083-2097 (2007)

Vieno, M., Dore, A.J., Stevenson, D.S., Doherty, R., Heal, M.R., Reis, S., Hallsworth, S., Tarrason, L., Wind, P., Fowler, D., Simpson, D., Sutton, M.A.: Modelling surface ozone during the 2003 heat-wave in the UK. Atmos. Chem. Phys. 10(16), 7963-7978 (2010). https://doi.org/10.5194/acp-10-7963-2010

Vingarzan, R.: A review of surface ozone background levels and trends. Atmos. Environ. 38(21), 3431-3442 (2004)

von Kuhlmann, R., Lawrence, M.G., Crutzen, P.J., Rasch, P.J.: A model for studies of tropospheric ozone and nonmethane hydrocarbons: Model evaluation of ozone-related species. J. Geophys. Res.Atmos. 108(D23), ACH 6-1-ACH 6-26 (2003)

Wałaszek, K., Kryza, M., Werner, M.: A Sensitivity Analysis of the WRF Model to Shortwave Radiation Schemes for Air Quality Purposes and Evaluation with Observational Data. In: D. Steyn \& R. Mathur (eds.) Air Pollution Modeling and its Applications XXIII, 539-543. Springer International Publishing (2014a). https://doi.org/10.1007/978-3-319-04379-1_89

Wałaszek, K., Kryza, M., Werner, M.: Evaluation of the WRF meteorological model results during a high ozone episode in SW Poland - the role of model initial conditions. Int. J. Environ. Pollut. 54(2/3/4), 193-202 (2014b)

Wałaszek, K., Kryza, M., Szymanowski, M., Werner, M., Ojrzyńska, H.: Sensitivity Study of Cloud Cover and Ozone Modeling to Microphysics Parameterization. Pure Appl. Geophys. (2016). https://doi.org/10.1007/s00024-015-1227-2

Werner, M., Kryza, M., Geels, C., Ellermann, T., Skjøth, C.A.: Ammonia Concentrations Over Europe Application of the WRF-Chem Model Supported with Dynamic Emission. Pol. J. Environ. Stud. 26(3), 1323-1341 (2017). 10.15244/pjoes/67340

Zhang, M., Uno, I., Zhang, R., Han, Z., Wang, Z., Pu, Y.: Evaluation of the Models-3 Community Multi-scale Air Quality (CMAQ) modeling system with observations obtained during the TRACE-P experiment: Comparison of ozone and its related species. Atmos. Environ. 40(26), 4874-4882 (2006)

Zhang, Y., Vijayaraghavan, K., Wen, X.-Y., Snell, H.E., Jacobson, M.Z.: Probing into regional ozone and particulate matter pollution in the United States: 1. A 1 year CMAQ simulation and evaluation using surface and satellite data. J. Geophys. Res. 114(D22), D22304 (2009)

Zwoździak, A., Sówka, I., Gzella, A., Zwoździak, J.: Morning ozone buildup during summer 2003 episodes and their links with some radiosonde data in Wroclaw, south-western Poland. Environ. Prot. Eng. 34(1), 63-79 (2008) 